\title{
Mechanisms of Intracellular Calcium Homeostasis in the Developing and Mature Bovine Corpora Lutea An In-Depth Study to Promote Scientific Literacy through the Use of Primary Literature in an Introductory Biology Course
}

Marietta Felicidad Wright

Follow this and additional works at: https://researchrepository.wvu.edu/etd

\section{Recommended Citation}

Wright, Marietta Felicidad, "Mechanisms of Intracellular Calcium Homeostasis in the Developing and Mature Bovine Corpora Lutea An In-Depth Study to Promote Scientific Literacy through the Use of Primary Literature in an Introductory Biology Course" (2013). Graduate Theses, Dissertations, and Problem Reports. 6977.

https://researchrepository.wvu.edu/etd/6977

This Dissertation is protected by copyright and/or related rights. It has been brought to you by the The Research Repository @ WVU with permission from the rights-holder(s). You are free to use this Dissertation in any way that is permitted by the copyright and related rights legislation that applies to your use. For other uses you must obtain permission from the rights-holder(s) directly, unless additional rights are indicated by a Creative Commons license in the record and/ or on the work itself. This Dissertation has been accepted for inclusion in WVU Graduate Theses, Dissertations, and Problem Reports collection by an authorized administrator of The Research Repository @ WVU.

For more information, please contact researchrepository@mail.wvu.edu. 


\title{
The Hydroclimatology of West Virginia Spatial and Temporal Trends and their Relationship with the North Atlantic Oscillation
}

\author{
Carson Wright
}

Thesis submitted

to the Davis College of Agriculture, Natural Resources, and Design at West Virginia University

in partial fulfillment of the requirements for the degree of

Master of Science in

Forestry

Dr. Nicolas Zegre, Ph.D., chair

Dr. Eungul Lee, Ph.D.

Dr. Michael Strager, Ph.D.

Division of Forestry and Natural Resources

Morgantown, West Virginia

2014

Keywords: Climate Change, Hydrology, Climate Variability, Mann Kendall, West Virginia, North Atlantic Oscillation

Copyright 2014 Carson Wright 


\title{
ABSTRACT \\ The Hydroclimatology of West Virginia Spatial and Temporal Trends and their Relationship with the North Atlantic Oscillation
}

\author{
Carson Wright
}

Global air temperature has risen $0.74^{\circ} \mathrm{C}$ over the last 100 years, and is one of several factors influencing climate and streamflow variability at global, regional, and local scales. The North Atlantic Oscillation (NAO) is another important factor contributing to climate variability by influencing the intensity of storms entering the eastern US. The Southeastern US is receiving less precipitation and streamflow is decreasing while the northeastern US is receiving greater amounts of precipitation and increasing streamflows. West Virginia is typically overlooked being on the border of both of these regions; therefore the objective of this study is to fill knowledge gaps surrounding WV's historical hydroclimatological trends. Understanding West Virginia's climate and streamflow variability is important to inform governmental policy about future problems related to water availability, water withdraws, and pollution loading. To investigate variability related to climatic change in West Virginia, we analyzed long term streamflow records (1930-2011) using the non-parametric Mann Kendall trend tests. The non-parametric Mann Kendall trend test was selected to assess for systematic change over time within nonnormally distributed streamflow data. In addition, NAO indices were correlated with modeled precipitation data and mean seasonal streamflow to investigate and characterize hydroclimatological variability. Results show that NAO is correlated with precipitation within West Virginia and that streamflow is increasing, however results show that streamflow is not correlated with NAO suggesting other controls not accounted for in this study. 


\section{Table of Contents}

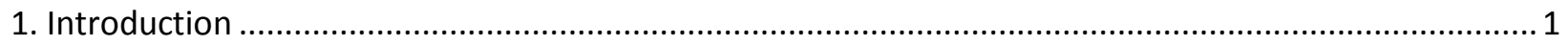

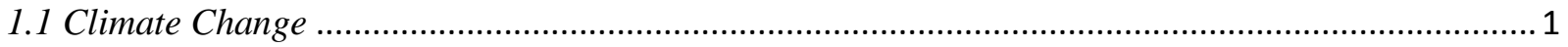

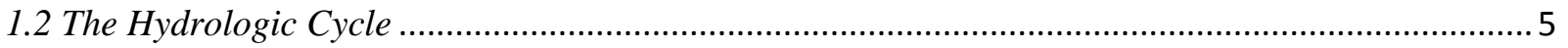

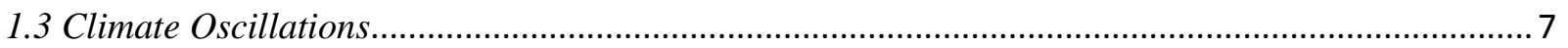

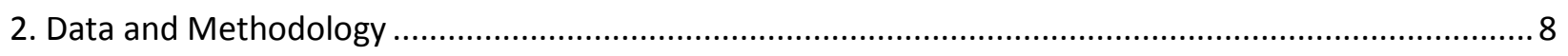

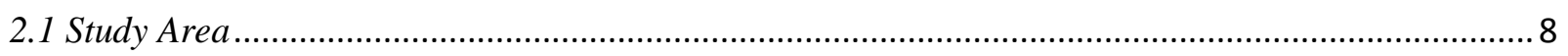

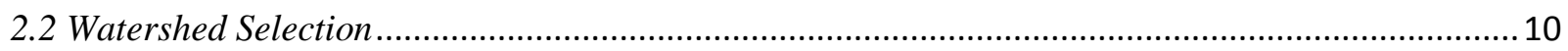

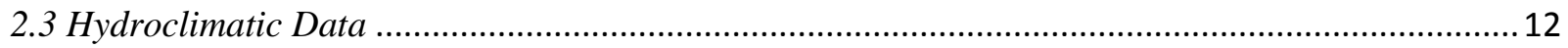

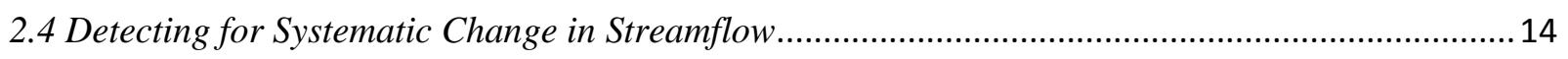

2.5 Correlating Streamflow with Climate ..................................................................................... 16

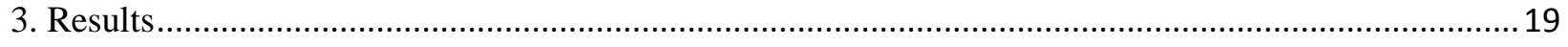

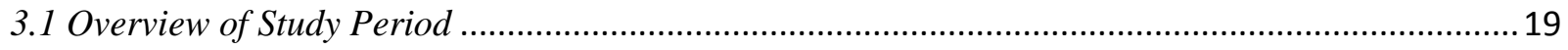

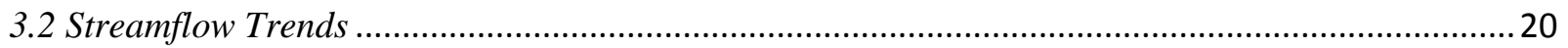

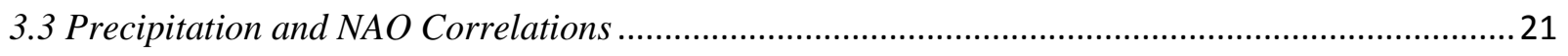

3.4 Mean Seasonal Streamflow and NAO Correlations................................................................. 21

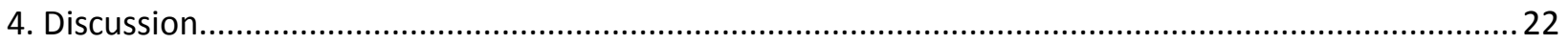

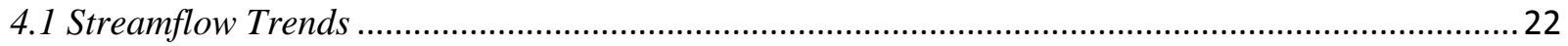

4.2 Mean Seasonal Streamflow and NAO Correlations.................................................................. 25

4.3 Implications to Water Resources Management.......................................................................... 26

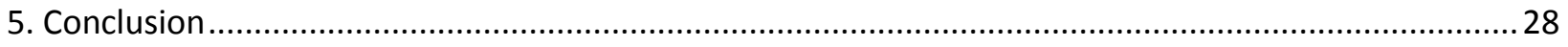

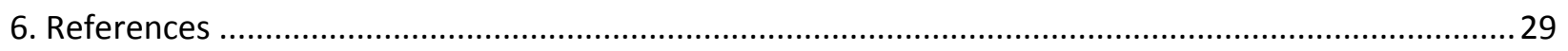

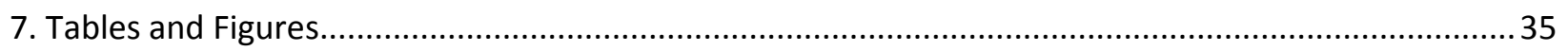




\section{Introduction}

\subsection{Climate Change}

Warming of global climate is evident from observations over the last several decades in mean global air temperature, ocean temperature, and widespread melting of polar ice sheets (IPCC 2007, 2013, Showstack 2013). According to the Intergovernmental Panel on Climate Change (IPCC), the mean global air temperature has increased $0.74^{\circ} \mathrm{C}$ from 1906 to 2008 (IPCC 2007, 2008). Long term observational hydroclimatic datasets provide important insights into understanding hydroclimatic phenomenon but the presence of nonstationarity induced through anthropogenic drivers and long-term persistence within datasets should not be ignored (Hirsch 2011). Stationarity assumes streamflow is constant over time while hydroclimatic drivers produce changing nonstationary streamflows. Air temperature is affected by both anthropogenic and natural drivers, but the greatest increase in air temperature during the latter part of the century is attributed to anthropogenic influences, (Burns et al. 2007, IPCC 2008) namely the release of greenhouse gases. Mean atmospheric carbon dioxide concentrations monitored at Mauna Loa Observatory in Hawaii, from 1959 to 2012 have increased from 315 ppm to 393 ppm driven by changes in climate (Observatory 2012). Scientists have established the general direction of global climate with increasing temperatures and intensification of global climate variability but the effects of climate change on regional climate and hydrology are uncertain. Extreme hydroclimatological events are the most detrimental to regions with low economic standing that lack adequate resources to mitigate extreme climatic events (Huntington 2006).

Studies show that changes in mean global air temperature and atmospheric $\mathrm{CO}_{2}$ concentrations are shifting regional hydroclimatology throughout the northeastern United States 
(Hayhoe et al. 2007). The northeastern region is defined as ranging from Maine to Maryland, and including Ohio and Pennsylvania. The mean air temperature across this region has exceeded the global average increasing by $1.1^{\circ} \mathrm{C}$ over the last century (Burns et al. 2007, Trombulak and Wolfson 2004). Along with increases in temperature, the northeast has experienced variable increases in precipitation approximately by $8 \%$ annually (Burns et al. 2007). Historical trends display the general direction of increasing precipitation and temperatures across the northeast in hydroclimatological patterns but considerable variability is encountered when investigating subregional spatial scales. Studies on regional climate throughout the northeast have been conducted to better understand water resources, especially related to high water demands from densely populated cities like New York and Philadelphia (Hayhoe et al. 2007, Vogel et al. 1997). Demand for water withdrawals throughout the northeast exacerbate hydrologic variability and introduce anthropogenic drivers which introduces additional complexities when detecting change in climatic and non-climatic signals (Hirsch 2011, Hsieh et al. 2007, Thomas and Pool 2006). The northeastern climate is becoming more variable but stability of water availability is still greater within the northeast than the southeastern U.S (Cayan et al. 2010, Seager et al. 2009).

The southeastern U.S. ranges from Florida to Mississippi with the northern border formed by Tennessee, North Carolina, and Virginia. The southeast historically has faced increasing industrial and drinking water withdraws from population growth inducing anthr6opogenic variability within hydrologic records accompanied by considerable climatic variability exacerbating extreme climatological events (Manuel 2008, Patterson et al. 2012, Seager et al. 2009). The population in Paulding County, Georgia alone, for example, has increased by $49 \%$ from 2000 to 2006, increasing demand for water resources and decreasing available water, contributing to $\$ 1.3$ billion in crop damage to corn, wheat, soybeans, cotton and hay during the 
winter drought in 2008 (Manuel 2008). In the later part of the $20^{\text {th }}$ century the south Atlantic region (Virginia, North Carolina, and South Carolina) sub-region of the southeast has experienced decreases in precipitation and streamflow along with increases in annual temperatures by nearly $1^{\circ} \mathrm{C}$ with winter monthly increasing by almost $2^{\circ} \mathrm{C}$ (Karl et al. 2009, Patterson et al. 2012). Decreasing precipitation and increasing temperatures regionally will limit water availability by likely increasing atmospheric water vapor, decreasing soil moisture content, and decreasing streamflow. Heavy precipitation along the coastal southeast not related to tropical cyclone activity increased by 21\% $100 \mathrm{yr}^{-1}$ from 1939-2002, but runoff decreased approximately 16\% simultaneously (Groisman 2002, Groisman et al. 2004). Southeastern U.S. hydroclimatological trends are highly variable within sub-regions and create complicated issues when attempting to downscale to finer spatial resolutions to apply regional trends to sub-regions to make informed policy and environmental decisions. Historical and future hydroclimatological trends throughout the northeast and southeast US have been investigated, and while conditions are highly variable, many studies provide supporting evidence of current and possibly future conditions (Burns et al. 2007, Hayhoe et al. 2007, Leonard and Law 2012, Manuel 2008). However few studies attempt to understand sub-regional hydroclimatology. The most neglected sub-regions are ones that encompass borders of multiple large U.S. regions like the Mid-Atlantic Region (MAR) located at the northern part of the southeast and the sourthern part of the northeast.

The MAR is primarily dominated by forests and agricultural lands encompassing Pennsylvania, Maryland, Delaware, Virginia, West Virginia and portions of New York, New Jersey, and North Carolina (Neff et al. 2000). The physiography throughout the MAR is highly variable including mountains, valleys, and coastal plains introducing considerable variability 
(Rogers and McCarty 2000). Historical temperature (1895-1997) has increased by $0.5^{\circ} \mathrm{C}$ for this region (Pitchford et al. 2011, Polsky et al. 2000), though both decreases in hot days ( $>32^{\circ} \mathrm{C}$ ) and increases in cold days $\left(<-18^{\circ} \mathrm{C}\right)$ has been identified within the region (Rogers and McCarty 2000). Precipitation has increased by $10 \%$ linearly over the past 100 years, and if this rate continues, stream channelization, wetland loss, sedimentation, nutrient mobilization, and anthropogenic chemicals could potentially affect the sustainability of future water resources (Meyer and Pulliam 1992, Rogers and McCarty 2000, Watson et al. 1998). Increases in precipitation could be attributed to increased temperatures causing increases in evapotranspiration and greater atmospheric storage within the hydrologic cycle (Burns et al. 2007). Hydroclimatological shifts in environmental variables due to climate change throughout the MAR may disturb ranges of insects, invasive plants, forest composition, aquatic communities at both coastal and inland wetlands (Dukes and Mooney 1999, Iverson and Prasad 1998, Michaels et al. 1995, Rodríguez-Trelles et al. 1998). Sub-regional hydroclimatological variability is observed within the MAR between inland and coastal climate stations displaying inversed relationships for precipitation and temperature trends ( $W u$ 2010). The unique climate of the MAR is shifting towards a warmer and wetter state (Moore et al. 1997, Najjar et al. 2000, Neff et al. 2000, Pitchford et al. 2011, Rogers and McCarty 2000) but local spatial variability exists throughout the sub-regions of the MAR. Local scale hydroclimatology should be investigated throughout watersheds of the MAR with minimal presence of anthropogenic disturbance to limit the potential influences non-climatic variables have on droughts and extreme storm events related to increasing climate variability. 


\subsection{The Hydrologic Cycle}

The hydrologic cycle is a balance of inputs, outputs, and storage which is an energy mass balance with energy from solar radiation driving the cycle and water forming the mass moving through the Cycle. Physical processes are evapotranspiration, precipitation, interception, atmospheric storage, groundwater storage, and runoff/streamflow. When any single physical process is altered, changes can be transferred through the cycle, altering subsequent physical processes and creating feedback loops causing intensification of the hydrologic cycle (Huntington 2006). Global intensification of the hydrologic cycle is exacerbated by increases in $\mathrm{CO}_{2}$, rising temperatures, and increasing evapotranspiration, leading to more frequent extreme hydroclimatological events like tropical storms, floods, and droughts with amplification of warming trends through increases in water vapor feedback (Huntington 2006). Changes in high latitude global atmospheric temperatures can drive regional snow albedo feedbacks exacerbating temperature increases, while increases in low latitudes temperatures can increase evapotranspiration, increasing atmospheric water vapor, and reducing the rate of temperature increases (Hayhoe et al. 2007). Also as temperatures increase, the additional energy will likely increase evapotranspiration, which due to the Clausius-Clapeyron relation (warmer air holds more water vapor), the atmospheric storage should increase and runoff should decrease (Huntington 2006). Future projections in the MAR show increases in $\mathrm{CO}_{2}$ concentrations, increases in temperature, increases in storm severity and frequency, leading to increases in total precipitation, continual sea level rise, and increases in fire intensity by anthropogenic drivers and hydrologic cycle feedback loops (Houghton 1996, Najjar et al. 2000, Rogers and McCarty 2000).

The state of West Virginia provides a unique study area within the MAR with minimal 
anthropogenic influences compared to surrounding sub-regions. West Virginia’s population has slowly grown by approximately 1,820 people year ${ }^{-1}$ from 1,729,205 in 1930 to 1,856,680 in 2010, while West Virginia’s city populations have simultaneously decreased (2010, Leonard and Law 2012). While West Virginia's population is low, $60 \%$ of the eastern U.S. population is within 6 hours of the state borders. West Virginia's proximity to densely populated portions of the eastern U.S. while having minimal urbanization and landcover disturbance allows for more accurate response of climatic signals within the hydrologic record. Landcover across the state has succeeded towards forested conditions and between 1907 to 2002, forest cover increased from 9.1 million acres (61\%) to 12.1 million acres (79\%) of forests (Leonard and Law 2012, Smith et al. 2002). West Virginia is comprised of steep topography due to the bisecting mountain ranges and three physiographic provinces which include the Appalachian Plateaus, Valley and Ridge, and the Blue Ridge (Fenneman 1938, Wiley 2012, Wiley and Atkins 2010, Wiley et al. 2000). Due to the highly variable climatic patterns and influences of topographic lifting of storms, the state can be separated into two or more climatic divisions (Leonard and Law 2012, Wiley 2012). Precipitation ranges from 1,067 mm to 1,143 mm (Wiley 2012), the Appalachian Plateaus on the western side of the state receives the greatest quantity of precipitation due to orographic lifting on the western windward side of the Appalachian Mountains which occurs for the majority of precipitation events throughout the year. Orographic lifting occurs when air masses are mechanically lifted to high elevations due to topographic barriers, this causes the air masses to become saturated from the lower temperatures and precipitation. Harpers Ferry is located on the eastern most edge of the state in the Blue Ridge physiographic region receiving the least amount of precipitation which is contributed from the Atlantic Ocean and Gulf of Mexico. The eastern side of the Appalachian front receives precipitation from maritime tropical 
air masses (Wiley 2012) or from shifting winter storm tracks related to positive phase North Atlantic Oscillation (NAO). These physiographic regions combined with variable precipitation sources from the Gulf of Mexico, Atlantic Ocean, and Great Lakes creating highly variable climatic conditions throughout the state. West Virginia also forms portions of the headwaters for two major watersheds in the eastern U.S., which one supplies potable water to Washington DC via drainage to (1) the Chesapeake Bay and (2) the Gulf of Mexico watershed through the Ohio and Mississippi Rivers. Therefore, characterizing historical trends throughout West Virginia can provide insight into systematic change and availability of West Virginia's water resources and downstream regions.

\subsection{Climate Oscillations}

Relationships between hydroclimatic variables and global oscillation patterns like the already defined NAO, Atlantic Multidecadal Oscillation (AMO), and El Nino-Southern Oscillation (ENSO) are naturally occurring. The AMO is controlled by sea surface temperature (SST) and located over the Atlantic Ocean alternating between warm and cold SST's every 60 to 100 years (Enfield et al. 2001). Stepwise shifts during the 1970's in streamflow have been observed across the eastern U.S. and are thought to be related to increases in precipitation from a reversal in the AMO (Baines and Folland 2007, Enfield et al. 2001, Krakauer and Fung 2008, McCabe and Wolock 2002). When the AMO is in warm phase it decreases summer precipitation and influences the NAO towards negative phase by shifting the jet stream south and decreasing south Atlantic temperatures, reducing SST, and decreasing sea surface pressure particularly during the winter (McCabe and Wolock 2002). The NAO is also located over the Atlantic Ocean and is quantified through the normalized difference in mean sea level pressure between the Icelandic low pressure system in Iceland and the Azores high pressure system in Portugal and 
NAO is described as being either in a positive or negative phase. The movement of the jet stream influences the NAO; if the NAO is in positive phase, strong westerly storm systems will be pushed into the eastern U.S. increasing precipitation. During negative phase systems are pushed north of the eastern U.S. into Canada and the jet stream is shifted south and easterly winds dry out the eastern US. Climate is an integral factor in streamflow and oscillation influences on cyclonic activity have attributed to increases in fall precipitation throughout much of West Virginia increasing the likelihood of increased streamflow (Leonard and Law 2012).

The objectives of this study are to characterize the temporal trends in streamflow throughout West Virginia to improve hydroclimatological understanding of this rural underpopulated state that serves as an important headwater source to a large population of the US. The hypotheses of this study are (1) streamflow is changing systematically throughout West Virginia between 1930 and 2011 and (2) streamflow is greater throughout West Virginia during positive phase winter NAO. These hypotheses are tested through several statistical methods in this study, namely non-parametric Mann Kendall trend tests conducted on annual values to investigate for systematic change over time (Helsel and Hirsch 2002, Mann 1945, Patterson et al. 2012) and Spearman's Rho correlation to measure relationship strength between seasonal streamflows and winter NAO phase. The contribution of this study is to improve understanding and fill knowledge gaps of West Virginia’s historical hydroclimatology.

\section{Data and Methodology}

\subsection{Study Area}

West Virginia (Figure 1) is a heavily forested underpopulated state in the Appalachian Mountains of the eastern United States. Mean annual air temperature for West Virginia is $12^{\circ} \mathrm{C}$, but steep mountainous topography creates considerable climate variability (Leonard and Law 
2012, Wiley 2012). State-wide precipitation and temperature are susceptible to wide spatial variability due to the climatic divide, complex topography, physiographic regions, and seasonally shifting storm tracks (Carr 1990, Fenneman 1938, Leonard and Law 2012, Wiley 2012, Wiley and Atkins 2010, Wiley et al. 2000).

The climatic divide running along the western edge of the Valley and Ridge physiographic region from Maryland to Spruce Knob before shifting southwest and passing southeast of Beckley West Virginia contributes variability. Precipitation throughout most of the year is driven by westerly storm systems moving over the Appalachian Mountains increasing precipitation due to orographic lifting (Leonard and Law 2012, Wiley 2012). The majority of the state is within the less steep Appalachian Plateau west of the climatic divide that ranges from the western most state border across the Ohio Valley, eastward forming dendritic drainage patterns until transitioning to the Valley and Ridge at the Appalachian Mountains to the east (Wiley 2012). The Valley and Ridge spans from the western side of the Appalachian Mountains across the panhandle of the state forming trellised drainage patterns running parallel to the climatic divide (Wiley 2012). The Blue Ridge region comprises a small fraction on the easternmost border of the panhandle near Harpers Ferry WV, and also has trellised drainage patterns with steeper topography and wider valleys running parallel with the climatic divide (Wiley 2012).

The highest and lowest elevations are located in the eastern panhandle with Spruce Knob at 1,482 meters above mean sea level (AMSL) and Harpers Ferry at 73 meters AMSL. These ranging differences in topography and the climatic divide contribute great variability within precipitation (Leonard and Law 2012). State wide the average precipitation ranges from 1065 $1140 \mathrm{~mm} \mathrm{yr}^{-1}$ with the greatest precipitation falling along the climatic divide ranging from 1270 $-1524 \mathrm{~mm} \mathrm{yr}^{-1}$ due to orographic lifting on the windward side of the Appalachian mountains 
(Wiley 2012). The Ohio River Valley on the western border receives approximately $1010 \mathrm{~mm} \mathrm{yr}^{-}$

${ }^{1}$ from saturated westerly winds and relatively flat topography (Wiley 2012). The eastern

panhandle of the state receives the least amount of precipitation ranging from $760-890 \mathrm{~mm} \mathrm{yr}^{-1}$

due to being on the leeward side of the Appalachian mountains for the majority of the year

(Leonard and Law 2012, Wiley 2012). Snowfall follows the same general distribution across the

state as precipitation is greatly influenced by physiographic regions, topography, and the climatic

divide. During the fall increased cyclonic activity causes storms to travel north up the eastern

United States contributing precipitation from both the Gulf of Mexico and the Atlantic Ocean.

Due to westerly winds driving cyclonic related storm systems to the east and over the Atlantic

Ocean, fall cyclonic activity affects the eastern side of the climatic divide greater than the

western side. West Virginia is nested in the Gulf of Mexico and Chesapeake Bay watersheds

which are separated by the Appalachian Mountains. The majority of West Virginia's

precipitation is provided by westerly storms greater amounts of precipitation fall within the Gulf

of Mexico watershed (Leonard and Law 2012, Wiley 2012).

\subsection{Watershed Selection}

West Virginia has approximately 140 active USGS gauging stations installed across the state on streams, rivers, dams, reservoirs, and lakes. Out of the 140 stations available 16 were selected that fulfilled the necessary criteria to investigate for change over time (Table 1). The following criteria was used to select stations (1) unregulated flow (i.e. absence of dams and water control structures); daily discharge from 1930 - 2011; (2) long term (1930-2011) daily discharge; (3) > 9 months of daily discharge per year; (4) and no gaps exceeding 4 years consecutively (Helsel and Hirsch 2002, Mann 1945). The only exception to these criteria is the 
West Fork Little Kanawha River at Rocksdale that has daily discharge from 1929 - 1975; this station was used to increase spatial distribution of gauging stations. When investigating for systematic changes over time the longer the time series of hydroclimatological records the less likely non-stationarity is to influence trends due to short term fluctuations (Hirsch 2011). The final part of the analysis was to investigate the landscape characteristics within the watershed for potential drivers of variability we characterized mean slope, drainage area, percent forest cover, percent impervious surface, drainage direction, drainage density, and channel sinuosity. The landscape analysis used a 10 meter digital elevation model (DEM) derived from hypsography at a 1:24,000 scale of West Virginia and surrounding regions, the DEM was used to delineate the watersheds through ArcToolbox’s Spatial Analyst hydrology tool. The delineated watersheds were then masked to land cover and the DEM to evaluate each watershed's attributes. The climatic divide bisects the state with 10 stations on the western side of the divide and 6 on the eastern side. Eleven stations are located in the Appalachian Plateaus, 4 in the Ridge and Valley, and 1 in the Blue Ridge region (Figure 7). Elevations range from 89 - 1,482 meters AMSL which influences hydroclimatology (Leonard and Law 2012). Watershed areas range from 222 - 3,784 square kilometers; mean slopes range from 5.6 - 74 degrees; and mean stream channel slopes range from 0.2 to 32 degrees. The primary landcover in all 16 watersheds is deciduous forest cover ranging from $47 \%$ in the Shenandoah River at Millville, to $90 \%$ in the Little Kanawha River at Rocksdale. The characterization of watershed attributes is important due to wide variability across the state due to the climatic divide, physiographic differences, topographic relief, and prevailing wind patterns. 


\subsection{Hydroclimatic Data}

The data sets utilized in this study came from the United States Geological Survey (USGS), National Center for Atmospheric Research (NCAR), and the Climate Research Unit (CRU). The streamflow observational data provided by the USGS was collected with stream gauging stations around the state and is accessed through the National Water Information System Network. The USGS regularly monitors the streamgauge network to conduct intensive quality assurance and quality control on data collection and equipment, along with manually truthing streamflow for comparisons with the automated streamgauge estimates.

Four hydrologic metrics were defined to evaluate for changes in hydrology: minimum annual daily discharge (Qmin); maximum annual daily discharge (Qmax); mean annual daily discharge (Qmean); and median annual daily discharge (Qmed) (Leonard and Law 2012, McCabe and Wolock 2002). These hydrologic metrics provide different insights into West Virginia’s general hydrologic conditions; the minimum flow trends are important when concerning water availability for municipal water treatment facilities and total maximum daily loads for waterways; the maximum daily flow trends relate flood regimes to water infrastructure (i.e. bridges, dams, and spill ways) that might experience increasing flood conditions; the mean and median provide insight into the general trend directions of streamflow to support overall hydroclimatological conditions.

For this study we used two NAO indices: the CRU mean monthly index and Hurrell NAO mean winter (DJFM) index. The NAO indices used came from the NCAR station based Hurrell NAO mean winter index and the CRU mean monthly index. The CRU mean monthly NAO index is derived from the difference in normalized sea surface pressure between Ponta

Delgada, Portugal and Reykjavik, Iceland. The Hurrell index is produced from the normalized 
sea surface pressure differences between Lisbon, Portugal and Stykkisholmur/Reykjavik, Iceland (Hurrell 1995a). Two primary limitations of NAO are that (1) stations are fixed spatially and do not measure the centroid of the pressure system which would allow a more precise measure of NAO conditions; and (2) that effects of small scale meteorological events such as small storm systems rapidly changing station pressure for several hours creates short term variability and noise within data skewing daily means. The excessive noise within NAO due to these events is why monthly, seasonal, and annual scales are primarily used to investigate trends within NAO (Bradbury et al. 2002, Bradbury et al. 2003, Hurrell and Van Loon 1997). Strengths to the station based indices are that (1) data dates back to the 1860's providing longterm record, (2) the indices are simple to understand, and (3) since indices are representative of the entire region, they are easier to construct and use.

In the northeastern US, winter NAO phase has the greatest seasonal influence and increases streamflow variability throughout the year due to lag effects (Coleman and Budikova 2013, Hurrell 1995b, Rogers 1997, Serreze et al. 1997). Atmospheric oscillation regimes influence climate variability which potentially cause responses in streamflow variability, especially during extreme phases of the NAO (Coleman and Budikova 2013). Climate significantly impacts streamflow in some catchments, and climatic events potentially have greater impacts on streamflow variability during large storm events than land cover change (Kochenderfer et al. 2007). To investigate the role NAO has on streamflow variability, gridded seasonal (DJF) precipitation ( $0.5^{\circ}$ latitude by $0.5^{\circ}$ longitude) data for the study area was acquired from the CRU. This data was produced from precipitation observations at over 11,880 stations in the Global Historical Climatology Network (Hulme et al. 1998). The historical precipitation observations were interpolated into gridded data through the thiessen polygon method. 
Therefore, winter NAO was used in this study to correlate streamflow and gridded precipitation data from the CRU with mean winter NAO.

\subsection{Detecting for Systematic Change in Streamflow}

The Tau-b Mann Kendall (MK) test (Hamed and Rao 1998, Helsel and Hirsch 2002, Mann 1945, Sen 1968) was used to test for systematic changes in annual streamflow metrics. The MK is a ranked-sum test that requires independent and evenly spaced data (Helsel and Hirsch 2002, Mann 1945). The strength of the MK allows unit transformations, non-normal distribution, and is resistant to outliers (Helsel and Hirsch 2002, Mann 1945, Sen 1968). Tau-b for the MK is computed as:

$\tau_{B}=\frac{\eta_{c}-\eta_{d}}{\sqrt{\left(\eta_{0}-\eta_{1}\right)\left(\eta_{0}-\eta_{2}\right)}}$

Where $\eta_{0}=\eta(\eta-1) / 2, \eta_{1}=\sum_{i} t_{i}\left(t_{i}-1\right) / 2$, and $\eta_{2}=\sum_{j} t_{j}\left(t_{j}-1\right) / 2 \cdot \eta_{c}$ and $\eta_{d}$ are the number of concordant and discordant pairs respectively. $t_{i}$ and $t_{j}$ are the number of tied values in the $i^{t h}$ and $j^{t h}$ group of ties for the first quantity respectively.

The pairs of data are ordered from lowest to highest according to the $\mathrm{x}$ values denoted as the $i^{t h}$ group. The concordant and discordant values are calculated for each pair. Concordant values are computed by counting the number of ranks below the rank of interest that have greater $i^{\text {th }}$ values, while discordant values are computed by the number of ranks below the rank of interest which have a smaller value denoted as the $j^{\text {th }}$ group. The difference between the summation of the concordant and discordant ranks is the numerator for tau-b (equation 1). The denominator is calculated by first computing $\eta_{1}$ and $\eta_{2}$ by summing the number of tied values in each group separately, and subtracting one from each group and dividing by two. The groups are 
then multiplied together and the square root of the product denotes the denominator. Tau-b expresses the strength of the relationship between two variables ranging from -1 to +1 a perfectly negative correlation and perfectly positive correlation respectively. The MK test requires independent randomly ordered data (Hamed and Rao 1998). If auto correlation is identified, future observations are dependent upon past observations, which causes past observations to be a confounding variable (Hamed and Rao 1998). If independence does not exist and the MK is applied, pseudo trends will be identified and p-values will be incorrect. In this study, temporal autocorrelation was tested using the Partial Autocorrelation Function (PACF). Partial correlation is defined as the variability between two mutually correlated variables. The PACF quantifies the partial correlation variability within each time lag to determine if that variability is introduced into higher order lags (Gilbert 1987, Helsel and Hirsch 2002, Nau). If autocorrelation is detected then the MMK utilizes the Sen's method to generate independence within the time series. To generate independence in autocorrelated time series data, the MMK fits a Sen Slope before subtracting the difference between the Sen Slope and each observed data value. A second Sen Slope is fitted to the adjusted dataset, and the second Sen Slope is independent and comparable with the trends computed through the MK (Hamed and Rao 1998). Trend analyses were conducted for minimum, maximum, mean, and median daily discharge.

Sen’s nonparametric estimator of slope was computed to estimate constant systematic change in measurement per change in time, which denotes constant annual change in streamflow per year. The Sen’s method estimator has similar requirements as the MK; it requires evenly spaced time intervals, allows data gaps, allows non-normal data distribution, and is resistant to outliers (Sen 1968). Sen's equation is computed for each lag then multiplied by the total number of lags to calculate total change in streamflow: 
$\mathrm{Q}=\frac{X i^{\prime}-X i}{\mathrm{i}^{\prime}-\mathrm{i}}$

The Sen's equation is defined as $\mathrm{Q}$ is the slope between streamflow measurements, $\mathrm{Xi}$ is streamflow at time $i$ ', $\mathrm{X} i$ is streamflow at time I, and i' is time after time $\mathrm{i}$.

\subsection{Correlating Streamflow with Climate}

To correlate streamflow with climate relationships were tested using a Pearson’s linear regression model and Spearman's Rho. Correlation analyses were conducted between the CRU's Monthly NAO index, CRU's HadCM2 modeled precipitation, and the Hurrell Winter (Dec-Mar) NAO index data. The statistical package "R" was used for correlating the mean winter NAO and mean seasonal streamflow to determine the relationship between winter phase NAO and mean seasonal streamflow. This analysis was used to test the second hypothesis that streamflow is greater throughout West Virginia during positive phase winter NAO.

The first analysis was investigating for supporting evidence that mean winter NAO influences precipitation within West Virginia. The mean winter seasonal precipitation time series was extracted from the gridded CRU modeled data through Grid Analysis and Display System (GrADS) software. This programmable interface can handle regular, non-linearly spaced, gaussian, or variable resolution grids. To provide supporting evidence of relationships between NAO and precipitation, after extracting precipitation data in GrADS the Pearson's r correlations were conducted $(\boldsymbol{\alpha}=0.05)$. 
$r=\frac{1}{n-1} \sum_{i=1}^{n}\left(\frac{x_{i}-\bar{x}}{s_{x}}\right)\left(\frac{y_{i}-\bar{y}}{s_{y}}\right)$

The variables within Pearson's $\mathrm{r}$ are $\bar{x}$ equals the mean of $\mathrm{x}, \bar{y}$ equals mean of $\mathrm{y}, s_{x}$ equals standard deviation of $\mathrm{x}$, and $s_{y}$ equals standard deviation of $\mathrm{y}$.

The requirements for this statistical test are (1) approximately normal distribution, (2) data organized as intervals or ratios, (3) outliers are kept to a minimum or removed, (4) and homoscedasticity or constant variance. The Pearson correlation provides an r value ranging from -1 to +1 conveying the linear strength of the relationship between variables, such as mean winter NAO and mean spring runoff. This relationship is expressed as either a negative correlation, meaning as $\mathrm{y}$ values decrease $\mathrm{x}$ values increase; or a positive correlation, as y values increase $\mathrm{x}$ values increase (Helsel and Hirsch 2002). The relationship strength is highly dependent upon the number of degrees of freedom and the nature of the variables being measured, but typically an $\mathrm{r}$ of 0.1 to 0.3 and $\quad-0.1$ to -0.3 is a weak correlation, 0.3 to 0.5 and -0.3 to -0.5 is a medium correlation, and 0.5 to 1.0 and -0.5 to -1.0 is a strong correlation. Seasonal Pearson's r correlations were constructed between mean winter (DJFM) NAO and mean seasonal streamflow for winter (DJF), spring (MAM), summer (JJA), and fall (SON).

Analyses were conducted between mean winter (NAO) indices and seasonal Qmean using spearman's rho. These analyses utilized the CRU monthly index and the Hurrell NAO mean winter index. These indices were utilized to consider if there was a difference in variability between two common NAO indices. Spearman's rho is typically used when the requirements of linearity, normality, and homoscedasticity are not met. Spearman’s rho is a non-parametric ranked correlation that is similar to Kendall's tau. Spearman's rho performs a linear correlation on the ranks of data (Helsel and Hirsch 2002). To compute rho, X and Y values were ranked 
within pairs, the greatest value for $\mathrm{X}$ and $\mathrm{Y}$ is ranked as 1 and the smallest value equals the sample size. The difference between $\mathrm{X}$ and $\mathrm{Y}$ within pairs is computed and squared. The squared values are then summed, and the summation is denoted as $d$ in equation 4. Rho ranges from -1 to +1 similarly to Kendall's tau, but rho values are generally greater in magnitude. A rho value of 0.90 is approximately equivalent to a Kendall's Tau of 0.75 (Helsel and Hirsch 2002)

$$
\rho=1-\frac{6 \sum d_{i}^{2}}{n\left(n^{2}-1\right)}
$$

The variables within Spearman's rho are defined as $d$ equals the difference between paired ranks and $n$ equals the number of paired ranks.

The first Spearman's correlation utilized the mean winter (DJF) NAO from the CRU and mean seasonal streamflow. This analysis displayed significance in two seasons with low positive rho values at only the West Fork Little Kanawha River gauging station, but correlations are likely due to persistence related to the shortened time series of thirty-eight years. The second spearman's correlation was conducted with the same seasonal Qmean seasonal and winter NAO index from the CRU but included the month of March within the winter index. This correlation analysis showed no significant trends at any gauging stations. The third spearman correlation was conducted with the same seasonal Qmean, but the Hurrell mean winter (DJFM) NAO index was utilized. This correlation provided the same seasonal significance with low rho correlation values for the Little Kanawha River gauging stations. 


\section{Results}

In this section, results are presented for: (1) mean daily streamflow statistics, (2) annual minimum, mean, median, and maximum streamflow trends, (3) annual precipitation and mean winter NAO correlations, and (4) mean seasonal streamflow and mean winter NAO correlations. Mean daily streamflow statistics revealed several distinct patterns between watershed characteristics and streamflow metrics particularly around 1970. Annual streamflow metrics were evaluated for systematic change over time with considerable variability across watersheds. Hydroclimatic correlations and trends were assessed at seasonal timescales driven by the NAO throughout the eastern US during the winter (Bradbury et al. 2003, Rogers 1997, Serreze et al. 1997). Distinct differences were identified within summary statistics, trends, and correlations over the study period and between physiographic regions.

\subsection{Overview of Study Period}

Summary statistics exhibited variability between streamflow metrics and physiographic regions (Table 2). Watersheds displayed similar minimum daily streamflows across all physiographic regions with the exception of the South Branch Potomac River near Petersburg watershed. Watersheds in the Appalachian Plateau exhibited the highest streamflows across the three regions, followed by the Valley and Ridge, then Blue Ridge. The higher streamflows throughout the Appalachian Plateau are likely related to the lower energy, higher order streams. Mean and median streamflows were similar across physiographic regions except when extreme events skewed the mean. Median streamflows were highest in the Appalachian Plateau, followed by the Valley and Ridge, then Blue Ridge. Watersheds in the Appalachian Plateaus had the highest median streamflows followed by the Valley and Ridge, then Blue Ridge. The Valley and 
Ridge contained 3 of the 4 highest maximum streamflows, likely a result of increased elevations creating orographic lifting and intense precipitation. The Appalachian Plateau had the second highest maximum streamflow, followed by the Blue Ridge. Streamflow standard deviations were highest in the Appalachian Plateau and lowest in the Blue Ridge. Larger standard deviations were observed across all regions in watersheds with smaller drainage areas. Overall, summary statistics provided informative insights about the variability between physiographic regions and streamflow metrics but do not consider the aforementioned changes in variability related to the observed shift in streamflow during the 1970's (Baines and Folland 2007, McCabe and Wolock 2002) (Figure 2). When comparing pre-1970 to post-1970 daily streamflow, substantial differences in daily minimum, mean, median, and maximum streamflow variability are seen (Figure 3-6).

\subsection{Streamflow Trends}

Few watersheds exhibited significant trends in annual hydrology over the study period (1930-2011) displaying great variability . However, all significant trends were increasing (Table 3). There were 15 significant trends in the Appalachian Plateau, followed by 2 in the Valley and Ridge, and no trends for the single watershed in the Blue Ridge. Five significant increasing trends were detected for minimum streamflow, with 4 in the Appalachian Plateau and 1 in the Valley and Ridge that had the lowest increasing trend rate. Two significant increasing trends were detected for mean streamflow at nested watersheds in the Appalachian Plateau. Eight significant increasing trends for median streamflow were detected in the Appalachian Plateau with no significant trends in the Valley and Ridge or the Blue Ridge. Two significant increasing trends for maximum streamflows were detected with similar slope magnitudes in both the Valley 
and Ridge and Appalachian Plateau. The few significant maximum trends are likely related to the high dependence of peakflows to extreme climatic events (Kochenderfer et al. 2007). No significant trends were found in the Blue Ridge physiographic region.

\subsection{Precipitation and NAO Correlations}

All significant correlations between precipitation and the NAO were in the Valley and Ridge and Appalachian Plateau (Table 4). The majority of significant correlations were along the climatic divide (Figure 7) indicating possible associations between topographic relief, precipitation, and the NAO. There were 5 significant correlations with 3 in the Valley and Ridge and 2 in the Appalachian Plateau. The West Fork Little Kanawha River at Rocksdale in the Appalachian Plateau displayed the only significant correlation for watersheds on the western side of the climatic divide (Figure 7) likely due to the shortened temporal scale. The strongest correlations were in watersheds located in the Valley and Ridge physiographic region, while the weakest significant correlations were at the West Fork Little Kanawha River at Rocksdale. These stronger correlations in the Valley and Ridge are likely influenced by topographic controls.

\subsection{Mean Seasonal Streamflow and NAO Correlations}

Correlations between mean seasonal streamflow and the three different NAO indices were evaluated using Spearman’s Rho. Correlations between mean seasonal streamflow and CRU mean winter (DJF) NAO (Table 5) exhibited two significant correlations for one watershed in the Appalachian Plateau. Another correlation that included the month of March displayed no significant correlations (Table 6). The third correlation between mean seasonal streamflow and 
Hurrell mean winter (DJFM) NAO (Table 7) exhibited the same two significant correlations in the Appalachian Plateau as the 1st correlation.

\section{Discussion}

\subsection{Streamflow Trends}

There are several ways to evaluate for trends in hydrometric data: flow duration curves, monotonic trend tests, two sample step trend tests, parametric tests, and non-parametric tests (Helsel and Hirsch 2002). Each one of these methods has requirements that must be met which are frequently assumed and not tested. One requirement of the Mann Kendall trend test is the absence of autocorrelation in streamflow time series which is more frequent at shorter time intervals (Bence 1995, Helsel and Hirsch 2002). Autocorrelation was tested for in this study and when present the modified Mann Kendall was used to remove autocorrelation. Our study is unique by accounting for autocorrelation which is not performed in recent hydroclimatology studies (i.e. Burns at al. 2007 and Patterson et al. 2012).

Few significant streamflow trends were exhibited over the study period. The low number of significant trends is likely due to unaccounted for climatic and landscape controls on streamflow. Increasing streamflows have been observed throughout much of the US similarly to the results in our study (Baines and Folland 2007, Lins and Slack 1999, McCabe and Wolock 2002). An increasing streamflow step wise shift was observed during the 1970's (Figure 2) increasing variability, and likely influencing trends throughout West Virginia. Streamflow variability is also influenced by other controls such as minimum streamflows being highly dependent on groundwater particularly during the summer season (Wiley 2012, 2006a), while unlike the mean, median streamflows are resistant to being skewed by extreme climatic events (McCabe and Wolock 2002). The majority of the significant trends are clustered in the northern 
part of the Appalachian Plateau (Figure 8). This clustering is likely related to streamflow variability in the Appalachian Plateau, (Table 2) from dendritic drainage patterns, reduced orographic precipitation, and greater forest cover (Table 8) (Leonard and Law 2012, Wiley 2012, 2006b). Mean and maximum streamflows exhibit greater dependence on climate due to the influence that precipitation has on peakflows (Kochenderfer et al. 2007, Singh 1997). Therefore West Virginia's rapidly changing elevation and multiple storm fronts combine to increase variability among the mean and maximum streamflows (Table 2) and likely decreasing the ability to detect significant trends, primarily in throughout the Valley and Ridge. Increased forest cover and large watershed areas reduced streamflow variability throughout the study region. The Shenandoah River at Millville had the lowest standard deviation, largest catchment area (7,876 $\mathrm{km}^{2}$ ), and 47 percent forest cover, but no significant trends. The streamflow variability for this large catchment in the Blue Ridge seemed to exhibit greater dependence on watershed area than forest cover percentage, since low forest cover percentages seemed to be associated with higher standard deviations throughout West Virginia.

The Big Coal River at Ashford and Tug Fork at Kermit in the southern portion of the Appalachian Plateaus have extensive landcover disturbance due to mountain top mining of coal (Zegre et al. 2014) but median and minimum streamflows were significant at both watersheds. Two significant trends at these watersheds in minimum streamflow (Table 3) had slopes nearly 3 times greater than other significant minimum trend slopes throughout West Virginia.

Goundwater dominates the greatest portion of runoff except during extreme precipitation events (Sklash and Farvolden 1979) which is likely contributing to significant trends in minimum and median streamflows at these watersheds. These trends provide evidence that disturbance related to mountain top removal could be increasing baseflows (Zegre et al. 2014), while peakflows and 
flooding are still highly dependent upon climate (Kochenderfer et al. 2007).

Few significant trends were exhibited throughout the Valley and Ridge (Figure 8) likely due to high streamflow variability overwhelming the ability to detect change present throughout the region (Table 2) (Zégre et al. 2010). This region contains 3 of the 4 highest maximum streamflows and also had the lowest median streamflows across the 3 physiographic regions. These highly variable streamflows are likely related to orographic precipitation skewing streamflow statistics (Roe 2005). The Valley and Ridge contains trellised drainage patterns, steeper, higher energy, headwater streams, that rapidly routes precipitation into streamflow, therefore increasing variability (Wiley 2006b). This increase in variability is particularly influential in maximum and mean streamflows and likely influencing change detection.

\subsection{Precipitation and NAO Correlations}

Climate throughout the Northeastern US, including West Virginia, is linked to the conditions of both the AMO and NAO (Bradbury et al. 2002, Bradbury et al. 2003, Enfield et al. 2001). The condition of the NAO from December to March is when the NAO has the greatest influence on eastern US climate, however the AMO influences the sea surface pressure which derives the NAO index (McCabe and Wolock 2002). Summer precipitation decreases when AMO is in warm phase, forcing the jet stream to shift south causing decreased south Atlantic temperatures, reduced sea surface temperature (SST), and decreased sea surface pressure (Krakauer and Fung 2008, McCabe and Wolock 2002, Seager et al. 2009). There was also a reversal in the AMO during the 1970's which could have influenced the step wise increase in streamflow observed throughout much of the eastern US (Baines and Folland 2007, Enfield et al. 2001, Krakauer and Fung 2008, McCabe and Wolock 2002). Therefor the NAO is not the only 
large scale oscillation that could be influencing precipitation throughout West Virginia.

Correlations between AMO and precipitation could provide further insights into precipitation patterns since higher SST in the South Atlantic Ocean would increase evaporation providing greater amounts of atmospheric water vapor to storms and more energy to transport storms into the eastern US (Enfield et al. 2001).

Few significant correlations were found between mean winter (DJFM) CRU NAO and mean winter (DJF) CRU precipitation (Table 4). The majority of significant trends were located on the eastern side of the climatic divide likely due to NAO influenced storm tracks moving southeast to northwest (Bradbury et al. 2003). When storms cross through West Virginia and over the Valley and Ridge, orographic precipitation is created throughout the region likely increasing the number of significant correlations. As these storms move northwest from the Valley and Ridge to the Appalachian Plateau they have less atmospheric water vapor and are at warmer lower elevations increasing atmospheric water holding capacity and reducing the likelihood of NAO driven precipitation (Coleman and Budikova 2013, Rogers 1984, Rogers 1997). The single significant catchment in the Appalachian Plateau (Table 4) has a shortened time period (1930-1975) that likely influences results due to nonstationarity (Hirsch 2011)

\subsection{Mean Seasonal Streamflow and NAO Correlations}

Results from the three spearman correlations evaluated in this study showed significant correlations for only one watershed in the Appalachian Plateau (Table 5-7), the West Fork Little Kanawha River at Rocksdale is capturing short term correlations (1930-1975) while the interest is on the long term historical correlations (1930-2011). The lack of correlations in watersheds over the study period from 1930-2011 suggest that there are other controls on streamflow than 
the NAO.

Streamflow is highly dependent on watershed physiography, landcover, and drainage basin area (Table 8-9) (Buttle and Eimers 2009, Enfield et al. 2001, Sen 2012). As mentioned, the increasing step shift in streamflow during the 1970’s could interfere with correlations between mean seasonal streamflow and the NAO (Baines and Folland 2007, Krakauer and Fung 2008, McCabe and Wolock 2002). This step increase in streamflow is particularly evident in the minimum (Figure 2) and median streamflows which are less susceptible to extreme climatic influences. Minimum streamflows are highly dependent upon groundwater inputs while the median streamflows are not skewed like mean streamflow is by extreme climatic events (Wiley 2006b).

The AMO also influences the quantity of precipitation throughout the US and could be influencing correlations between NAO and seasonal streamflow. The AMO experienced a warm phase from the 1930's to 1950's before shifting to a cool phase between the 1960's to 1980's, then transitioned back to warm during the 1980’s (Knight et al. 2006). The US receives increased rainfall and streamflow during cool AMO phase, while during warm AMO phase, the US receives decreased precipitation and streamflow (Knight et al. 2006). AMO phase reversals throughout the study period likely influenced the quantity of precipitation influencing streamflow throughout West Virginia and likely reducing significant correlations between mean seasonal streamflow and NAO.

\subsection{Implications to Water Resources Management}

Increasing streamflow trends throughout West Virginia suggest increases in surface water quantity resulting in greater water availability. These findings are important for determining 
water management priorities and emphasis throughout West Virginia’s large streamflow variability. Hydrology in West Virginia is similar to the northeastern US with increasing streamflows throughout much of the region but dissimilar to the South Atlantic region's decreasing streamflows (Burns et al. 2007, Hayhoe et al. 2007, Patterson et al. 2012, Polsky et al. 2000). Intensification of the hydrologic cycle is also occurring throughout West Virginia resulting in increases in the frequency of extreme hydrologic events (i.e. drought, flood, event frequency) (Huntington 2006).

Water infrastructure (i.e. bridges, culverts, water treatment plants) is constructed on the assumption that streamflow is stationary, but intensification of the hydrologic cycle may not support this assumption (Frederick and Gleick 1999, Hirsch 2011, Patterson et al. 2012). This assumption is evident to cause future flooding problems throughout West Virginia if water resources trends continue in the current increasing direction and infrastructures are not reassessed. Infrastructures are generally designed to the intensity and frequency of extreme climatic events (i.e. 100-year-storms) that occurred historically. However, this study displays evidence that intensity and frequency of extreme events is increasing (Figure 3-6) and these increases have the potential to compromise the safety and integrity of water infrastructures. The Appalachian Plateau in the north central part of the state should be emphasized for assessing water infrastructures due to the abundance of significant increasing trends (Figure 8). The Valley and Ridge had few significant increasing trends but summary statistics revealed the highest peakflows, identifying regions likely to flood. Only one watershed was assessed in the Blue Ridge that did have increased streamflow variability similarly to the other watersheds studies throughout West Virginia. These analyses provide evidence that continual monitoring and analysis of the non-stationary nature of West Virginia's hydroclimatology is necessary to 
maintain the water infrastructure and security into the future.

\section{Conclusion}

It is evident that climate change is occurring globally as mean global air temperature has risen approximately $0.74^{\circ} \mathrm{C}$ from 1906 to 2008 . Little is understood about the influence these global changes have on hydroclimatology. The South Atlantic region has become dryer while the MAR has become wetter but few studies have assessed the hydroclimatological changes that are occurring throughout West Virginia. To address this knowledge gap, we characterized the hydroclimatology of West Virginia through summary statistics, landcover analysis, non-parametric trend analysis, and correlation analysis. Streams were selected throughout the three physiographic regions of West Virginia that had minimal anthropogenic influences.

There were considerable differences between the Appalachian Plateau, Valley and Ridge, and Blue Ridge regions. However, all significant streamflow trends are increasing throughout West Virginia. These increasing trends could be driven by a step-wise increase in streamflow during the 1970's or precipitation increases throughout many portions of West Virginia (Wu 2010). Correlation analysis between the NAO and CRU precipitation exhibited significant positive correlations throughout the Valley and Ridge. These significant correlations are likely driven by storms first crossing higher elevations in the Valley and Ridge generating orographic precipitation and reducing the quantity of atmospheric water vapor crossing over the Appalachian Plateau. The seasonal correlation analyses between NAO and streamflow exhibited no significant correlations other than at the West Fork Little Kanawha River at Rocksdale which was likely due to the shortened temporal scale (1930-1975) of the watershed. If significant correlations did occur, they were expected at watersheds where significant correlations occurred between NAO and CRU precipitation. The lack of seasonal correlations between NAO and streamflow is an indication that there are stronger controls driving streamflow.

The results of this study suggest that the hydroclimatology throughout West Virginia is changing 
and that streamflow is increasing throughout most of the state. The NAO oscillation exhibited few significant correlations with streamflow which is likely due to landscape controls on streamflow or other oscillations having greater control on precipitation and streamflow such as the AMO. This study identifies the importance of continual monitoring of hydroclimatology throughout West Virginia to ensure the understanding and security of the state's stationary water infrastructure. Future studies should consider the impacts the AMO has on precipitation and streamflow, along with an assessment of the vulnerability increasing streamflows pose on stationary water infrastructure throughout the state.

\section{References}

Baines, P.G. and Folland, C.K. (2007) Evidence for a rapid global climate shift across the late 1960s. Journal of Climate 20(12).

Bence, J.R. (1995) Analysis of Short Time Series: Correcting for Autocorrelation. Ecology 76(2), 628-639.

Bradbury, J.A., Dingman, S.L. and Keim, B.D. (2002) New England Drought and Relations with Large Scale Atmospheric Circulation Patterns. JAWRA Journal of the American Water Resources Association 38(5), 1287-1299.

Bradbury, J.A., Keim, B.D. and Cameron, P.W. (2003) The Influence of Regional Storm Tracking and Teleconnections on Winter Precipitation in the Northeastern United States. Annals of the Association of American Geographers 93(3), 544-556.

Bureau, U.S.C. (2010) State and County.

Burns, D.A., Klaus, J. and McHale, M.R. (2007) Recent climate trends and implications for water resources in the Catskill Mountain region, New York, USA. Journal of Hydrology 336(1-2), 155-170.

Buttle, J.M. and Eimers, M.C. (2009) Scaling and physiographic controls on streamflow behaviour on the Precambrian Shield, south-central Ontario. Journal of Hydrology 374(3-4), 360-372.

Carr, J.E. (1990) National water summary 1987: Hydrologic events and water supply and use. US Geological Survey water-supply paper (USA).

Cayan, D.R., Das, T., Pierce, D.W., Barnett, T.P., Tyree, M. and Gershunov, A. (2010) Future dryness in the southwest US and the hydrology of the early 21st century drought. Proceedings of the National Academy of Sciences 107(50), 21271-21276. 
Coleman, J.S.M. and Budikova, D. (2013) Eastern U.S. summer streamflow during extreme phases of the North Atlantic oscillation. Journal of Geophysical Research: Atmospheres 118(10), 4181-4193.

Dukes, J.S. and Mooney, H.A. (1999) Does global change increase the success of biological invaders? Trends in Ecology \& Evolution 14(4), 135-139.

Enfield, D.B., Mestas-Nuñez, A.M. and Trimble, P.J. (2001) The Atlantic multidecadal oscillation and its relation to rainfall and river flows in the continental US. Geophysical Research Letters 28(10), 20772080.

Fenneman, N.M. (1938) physiography of eastern united states. 714 pp., illus. New York and London 122.

Frederick, K.D. and Gleick, P.H. (1999) Water \& global climate change: potential impacts on US water resources, Pew Center on Global Climate Change.

Gilbert, R.O. (1987) Statistical methods for environmental pollution monitoring.

Groisman, P.Y. (2002) Homogeneity issues in the global daily climatology network: Precipitation in cold climate regions.

Groisman, P.Y., Knight, R.W., Karl, T.R., Easterling, D.R., Sun, B. and Lawrimore, J.H. (2004)

Contemporary changes of the hydrological cycle over the contiguous United States: Trends derived from in situ observations. Journal of Hydrometeorology 5(1).

Hamed, K.H. and Rao, A. (1998) A modified Mann-Kendall trend test for autocorrelated data. Journal of Hydrology 204(1-4), 182-196.

Hayhoe, K., Wake, C., Huntington, T., Luo, L., Schwartz, M., Sheffield, J., Wood, E., Anderson, B., Bradbury, J., DeGaetano, A., Troy, T. and Wolfe, D. (2007) Past and future changes in climate and hydrological indicators in the US Northeast. Climate Dynamics 28(4), 381-407.

Helsel, D.R. and Hirsch, R.M. (2002) Statistical methods in water resources, US Geological survey Reston, Va.

Hirsch, R.M. (2011) A Perspective on Nonstationarity and Water Management. JAWRA Journal of the American Water Resources Association 47(3), 436-446.

Houghton, J.T. (1996) Climate change 1995: The science of climate change: contribution of working group I to the second assessment report of the Intergovernmental Panel on Climate Change, Cambridge University Press.

Hsieh, P.A., Barber, M.E., Contor, B.A., Hossain, M., Johnson, G.S., Jones, J.L. and Wylie, A.H. (2007) Ground-water flow model for the Spokane valley-Rathdrum prairie aquifer, Spokane County, Washington, and Bonner and Kootenai Counties, Idaho, US Geological Survey.

Hulme, M., Osborn, T.J. and Johns, T.C. (1998) Precipitation sensitivity to global warming: Comparison of observations with HadCM2 simulations. Geophysical Research Letters 25(17), 3379-3382. 
Huntington, T.G. (2006) Evidence for intensification of the global water cycle: Review and synthesis. Journal of Hydrology 319(1-4), 83-95.

Hurrell, J. (1995a) The Climate Data Guide: Hurrell North Atlantic Oscillation (NAO) Index (stationbased).

Hurrell, J.W. (1995b) Decadal Trends in the North Atlantic Oscillation: Regional Temperatures and Precipitation. Science 269(5224), 676-679.

Hurrell, J.W. and Van Loon, H. (1997) Decadal Variations in Climate Associated with the North Atlantic Oscillation. Climatic Change 36(3), 301-326.

IPCC (2013) Climate Change 2013: The Physical Science Basis, Intergovernmental Panel on Climate Change.

IPCC (2007) Climate Change 2007: The physical science basis.

IPCC (2008) Climate Change and Water. 210.

Iverson, L.R. and Prasad, A.M. (1998) Predicting Abundance of 80 Tree Species Following Climate Change in the Eastern United States. Ecological Monographs 68(4), 465-485.

Karl, T.R., Melillo, J.M. and Peterson, T.C. (2009) Global climate change impacts in the United States, Cambridge University Press.

Knight, J.R., Folland, C.K. and Scaife, A.A. (2006) Climate impacts of the Atlantic Multidecadal Oscillation. Geophysical Research Letters 33(17), L17706.

Kochenderfer, J.N., Adams, M.B., Miller, G.W. and Helvey, D.J. (2007) Factors affecting large peakflows on Appalachian watersheds: lessons from the Fernow Experimental Forest, p. 24, U.S. Department of Agriculture, Forest Service, Northern Research Station, Newtown Square, PA.

Krakauer, N. and Fung, I. (2008) Mapping and attribution of change in streamflow in the coterminous United States. Hydrology \& Earth System Sciences 12(4).

Leonard, J. and Law, K. (2012) Spatial and Temporal Variations in West Virginia's Precipitation, 19312000. Southeastern Geographer 52(1), 5-19.

Lins, H.F. and Slack, J.R. (1999) Streamflow trends in the United States. Geophysical Research Letters 26(2), 227-230.

Mann, H.B. (1945) Nonparametric Tests Against Trend. Econometrica 13(3), 245-259.

Manuel, J. (2008) Drought in the Southeast: Lessons for water management. Environmental health perspectives 116(4), A168.

McCabe, G.J. and Wolock, D.M. (2002) A step increase in streamflow in the conterminous United States. Geophysical Research Letters 29(24), 2185. 
Meyer, J. and Pulliam, W. (1992) Global Climate Change and Freshwater Ecosystems. Firth, P. and Fisher, S. (eds), pp. 177-191, Springer New York.

Michaels, G., O’Neal, K., Humphrey, J., Bell, K., Camacho, R. and Funk, R. (1995) Ecological impacts from climate change: An economic analysis of freshwater recreational fishing. Washington (DC): US Environmental Protection Agency, Office of Policy, Planning, and Evaluation, EPA 220-R-95-004.

Moore, M.V., Pace, M.L., Mather, J.R., Murdoch, P.S., Howarth, R.W., Folt, C.L., Chen, C.Y., Hemond, H.F., Flebbe, P.A. and Driscoll, C.T. (1997) Potential effects of climate change on freshwater ecosystems of the New England/Mid-Atlantic region. Hydrological Processes 11(8), 925-947.

Najjar, R.G., Walker, H.A., Anderson, P.J., Barron, E.J., Bord, R.J., Gibson, J.R., Kennedy, V.S., Knight, C.G., Megonigal, J.P., O'Connor, R.E., Polsky, C.D., Psuty, N.P., Richards, B.A., Sorenson, L.G., Steele, E.M. and Swanson, R.S. (2000) The potential impacts of climate change on the mid-Atlantic coastal region. Climate Research 14(3), 219-233.

Nau, R.F. Identifying the Numbers of AR or MA terms, Duke University Web

Neff, R., Chang, H., Knight, C.G., Najjar, R.G., Yarnal, B. and Walker, H.A. (2000) Impact of climate variation and change on Mid-Atlantic Region hydrology and water resources. Climate Research 14(3), 207-218.

Observatory, M.L. (2012) Mauna Loa CO2 annual mean data, Earth System Research Laboratory - Global Monitoring Division.

Patterson, L.A., Lutz, B. and Doyle, M.W. (2012) Streamflow Changes in the South Atlantic, United States During the Mid-and Late 20th Century1. JAWRA Journal of the American Water Resources Association 48(6), 1126-1138.

Pitchford, J., Wu, C., Lin, L., Petty, J., Thomas, R., Veselka, W., Welsch, D., Zegre, N. and Anderson, J. (2011) Climate Change Effects on Hydrology and Ecology of Wetlands in the Mid-Atlantic Highlands. Wetlands, 1-13.

Polsky, C., Allard, J., Currit, N., Crane, R. and Yarnal, B. (2000) The Mid-Atlantic Region and its climate: past, present, and future. Climate Research 14(3), 161-173.

Rodríguez-Trelles, F., Rodríguez, M.A. and Scheiner, S.M. (1998) Tracking the genetic effects of global warming: Drosophila and other model systems. C onse rvation Ecology 2(2).

Roe, G.H. (2005) Orographic Precipitation. Annual Review of Earth and Planetary Sciences 33(1), 645671.

Rogers, C.E. and McCarty, J.P. (2000) Climate change and ecosystems of the Mid-Atlantic Region. Climate Research 14(3), 235-244.

Rogers, J. (1984) The Association between the North Atlantic Oscillation and the Southern Oscillation in the Northern Hemisphere. Monthly Weather Review 112(10), 1999-2015. 
Rogers, J.C. (1997) North Atlantic storm track variability and its association to the North Atlantic Oscillation and climate variability of northern Europe. Journal of Climate 10(7), 1635-1647.

Seager, R., Tzanova, A. and Nakamura, J. (2009) Drought in the Southeastern United States: Causes, Variability over the Last Millennium, and the Potential for Future Hydroclimate Change. Journal of Climate 22(19), 5021-5045.

Sen, A.K. (2012) Streamflow variability in the Southern Appalachians and atmospheric teleconnections. River Research and Applications 28(5), 630-636.

Sen, P.K. (1968) Estimates of the Regression Coefficient Based on Kendall's Tau. Journal of the American Statistical Association 63(324), 1379-1389.

Serreze, M.C., Carse, F., Barry, R.G. and Rogers, J.C. (1997) Icelandic Low Cyclone Activity: Climatological Features, Linkages with the NAO, and Relationships with Recent Changes in the Northern Hemisphere Circulation. Journal of Climate 10(3), 453-464.

Showstack, R. (2013) IPCC Report Calls Climate Changes Unprecedented. Eos, Transactions American Geophysical Union 94(41), 363-363.

Singh, V.P. (1997) Effect of spatial and temporal variability in rainfall and watershed characteristics on stream flow hydrograph. Hydrological Processes 11(12), 1649-1669.

Sklash, M.G. and Farvolden, R.N. (1979) The role of groundwater in storm runoff. Journal of Hydrology 43(1-4), 45-65.

Smith, W.B., Vissage, J.S., Darr, D.R. and Sheffield, R.M. (2002) Forest Resources of the United States, 1997: Metric Units.

Thomas, B.E. and Pool, D.R. (2006) Trends in streamflow of the San Pedro River, southeastern Arizona, and regional trends in precipitation and streamflow in southeastern Arizona and southwestern New Mexico, US Department of the Interior, US Geological Survey.

Trombulak, S.C. and Wolfson, R. (2004) Twentieth-century climate change in New England and New York, USA. Geophysical Research Letters 31(19), L19202.

Vogel, R.M., Bell, C.J. and Fennessey, N.M. (1997) Climate, streamflow and water supply in the northeastern United States Journal of Hydrology 198(1), DOI: 10.1016/S0022-1694(1096)03327-03326.

Watson, R.T., Zinyowera, M.C. and Moss, R.H. (1998) The regional impacts of climate change: an assessment of vulnerability, Cambridge University Press.

Wiley, J.B. (2012) Comparison of Base Flows to Selected Streamflow Statistics Representative of 19302002 in West Virginia, p. 18, U.S. Geological Survey.

Wiley, J.B. (2006a) Low-Flow Analysis and Selected Flow Statistics Representative of 1930-2002 for Streamflow-Gaging Stations In or Near West Virginia, p. 198, U.S. Dept. of the Interior, U.S. Geological Survey, Charleston, W.V. 
Wiley, J.B. (2006b) Low-Flow Analysis and Selected Flow Statistics Representative of 1930-2002 for Streamflow-Gaging Stations In or Near West Virginia, p. 190, U.S. Gelogical Survey.

Wiley, J.B. and Atkins, J.T. (2010) Estimation of Flood-frequency Discharges for Rural, Unregulated Streams in West Virginia, US Department of the Interior, US Geological Survey.

Wiley, J.B., John T. Atkins, J. and Tasker, G.D. (2000) Estimating magnitude and frequency of peak discharges for rural, unregulated, streams in West Virginia.

Wu, C. (2010) Long-term climate trends in the Mid-Atlantic Region, USA, West Virginia University, Morgantown, WV.

Zégre, N., Skaugset, A.E., Som, N.A., McDonnell, J.J. and Ganio, L.M. (2010) In lieu of the paired catchment approach: Hydrologic model change detection at the catchment scale. Water Resources Research 46(11).

Zegre, N.P., Miller, A.J., Maxwell, A. and Lamont, S.J. (2014) Multiscale Analysis of Hydrology in a Mountaintop Mine-Impacted Watershed, p. 16, Journal of the American Water Resources Association 


\section{Tables and Figures}

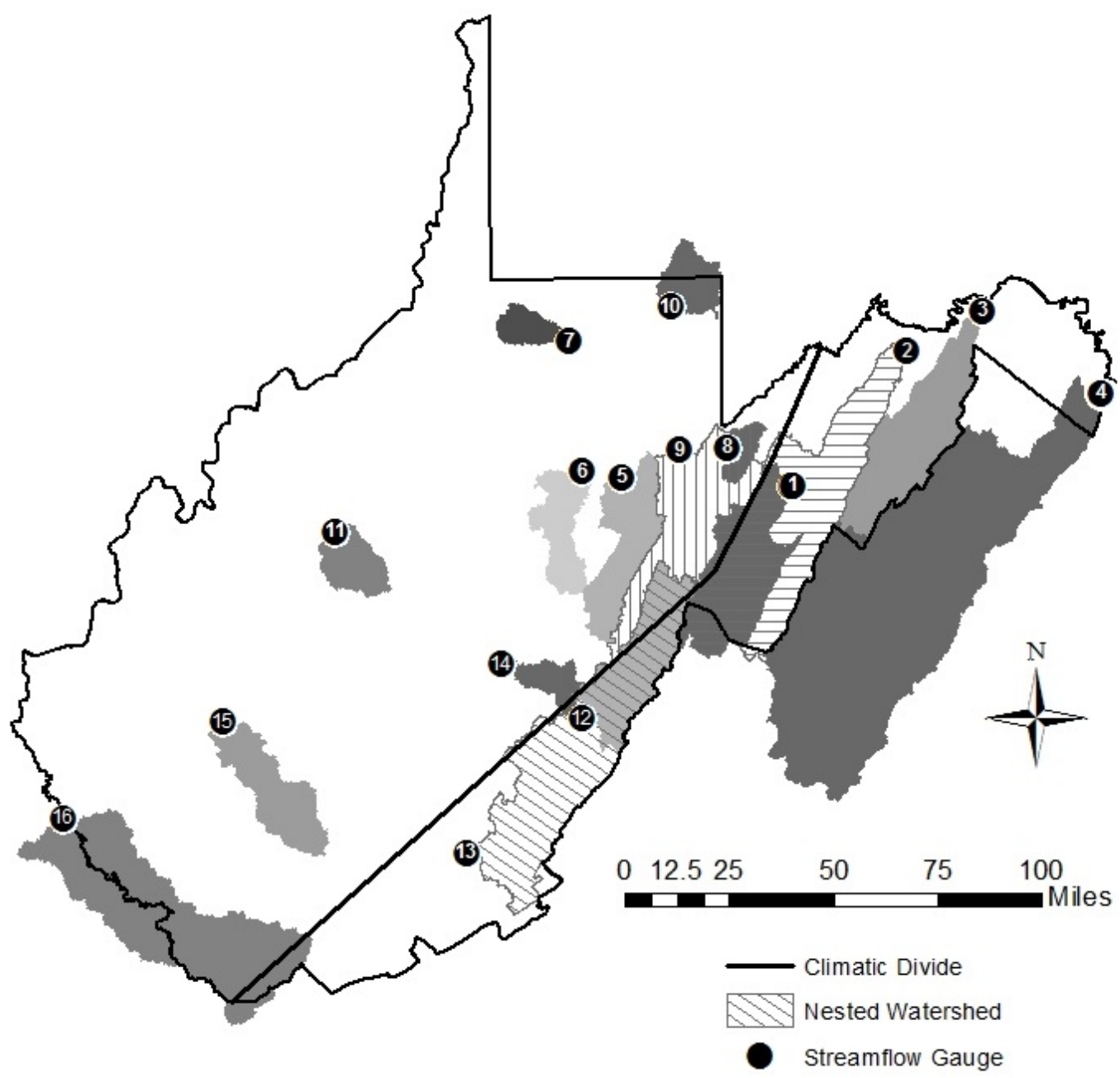

\begin{tabular}{|c|c|c|c|}
\hline 1 & South Branch Potomac River near Petersburg & 9 & Cheat River near Parsons \\
\hline 2 & South Branch Potomac River near Springfield & 10 & Big Sandy Creek at Rockville \\
\hline 3 & Cacapon River near Great Cacapon & 11 & West Fork Little Kanawha River at Rocksdale \\
\hline 4 & Shenandoah River at Millville & 12 & Greenbrier River at Buckeye \\
\hline 5 & Tygart Valley River at Belington & 13 & Greenbrier River at Alderson \\
\hline 6 & Buckhannon River at Hall & 14 & Williams River at Dyer \\
\hline 7 & Buffalo Creek at Barrackville & 15 & Big Coal River at Ashford \\
\hline 8 & Blackwater River at Davis & 16 & Tug Fork at Kermit \\
\hline
\end{tabular}

Figure 1. Locations of the 16 study watersheds throughout West Virginia. 


\section{Minimum Streamflow at Big Coal River at Ashford}

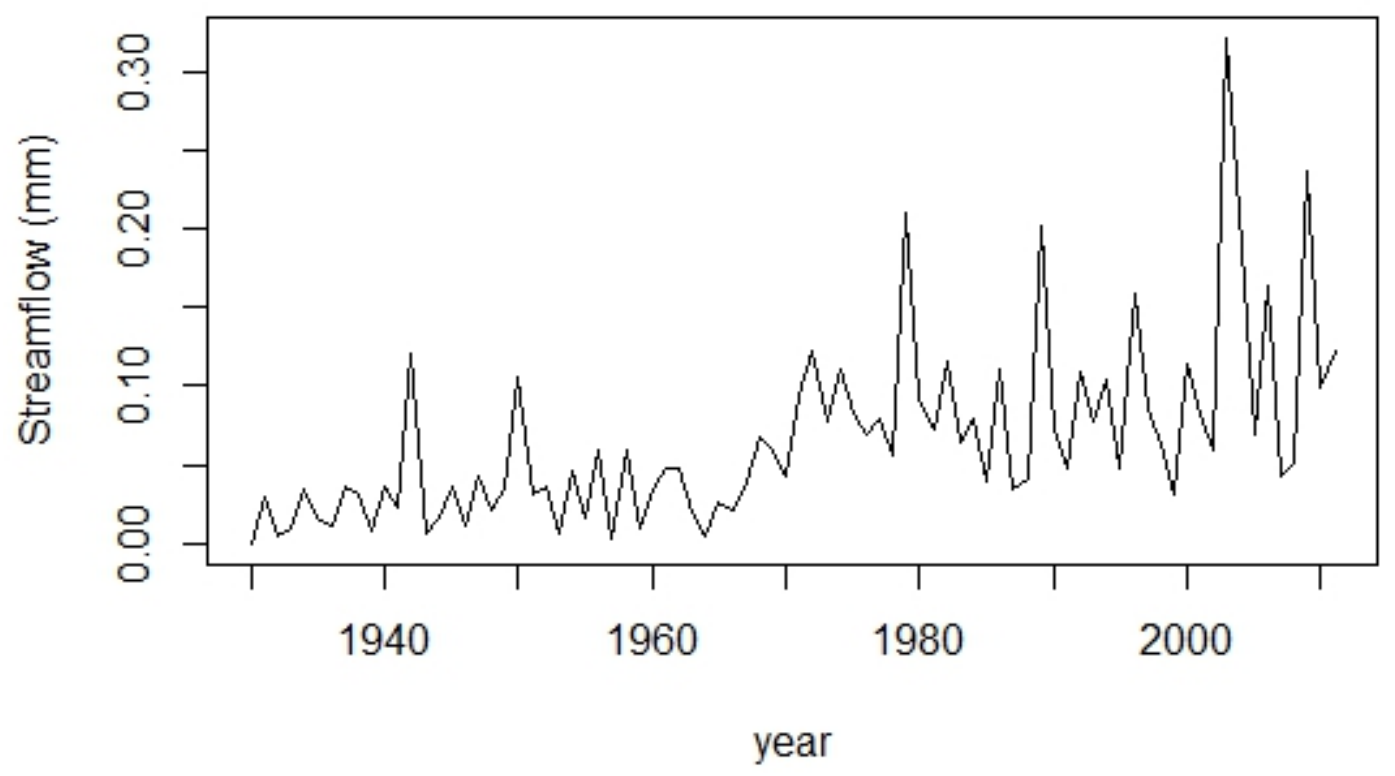

Figure 2. Minimum streamflow from 1930-2011 at the Big Coal River at Ashford displaying an increase in streamflow and variance around 1970. 


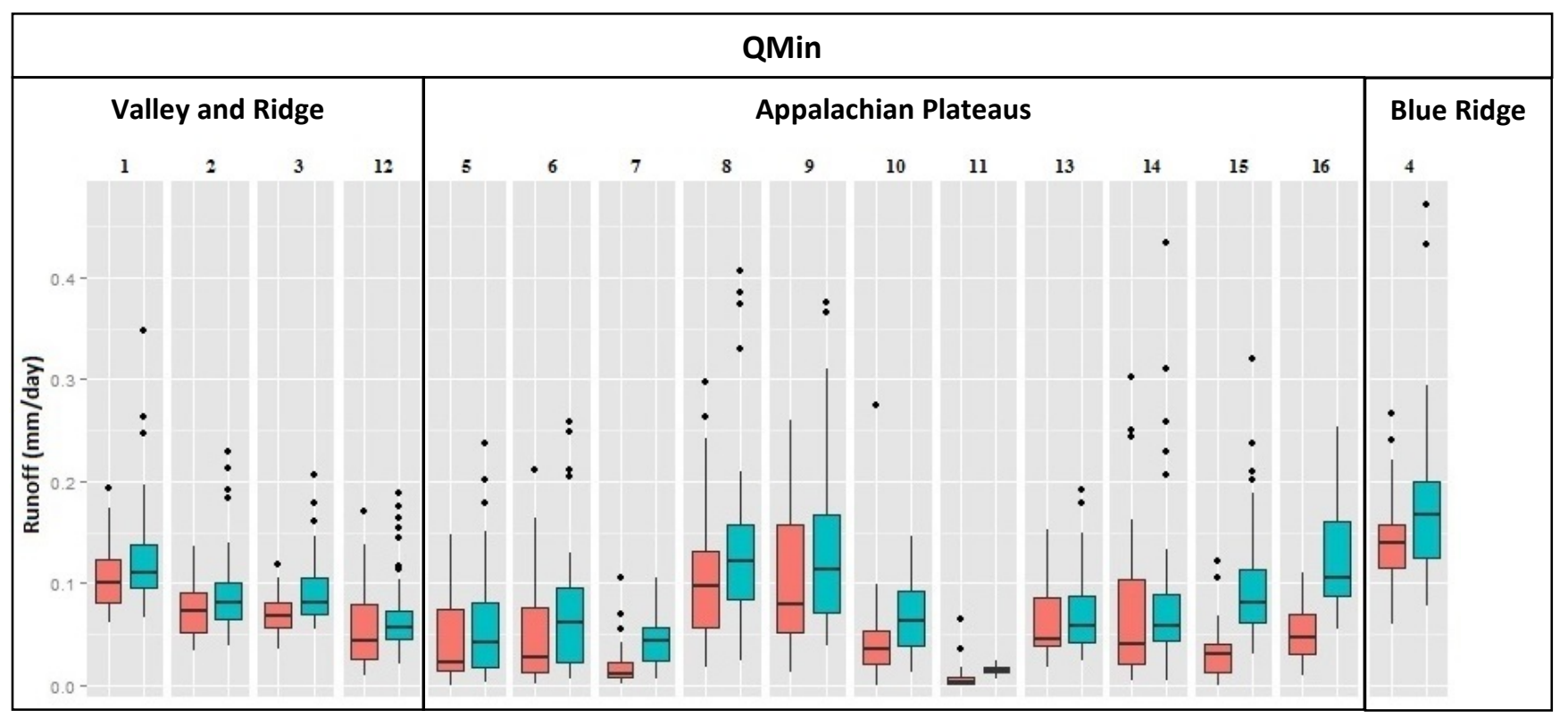

Figure 3. Pre to post 1970 comparison of Qmin daily streamflow, the first boxplot in each column is the pre 1970 boxplot and the second boxplot in each column is the post boxplot. The pre to post boxplots are displaying change related to a step shift in streamflow during the early 1970's.

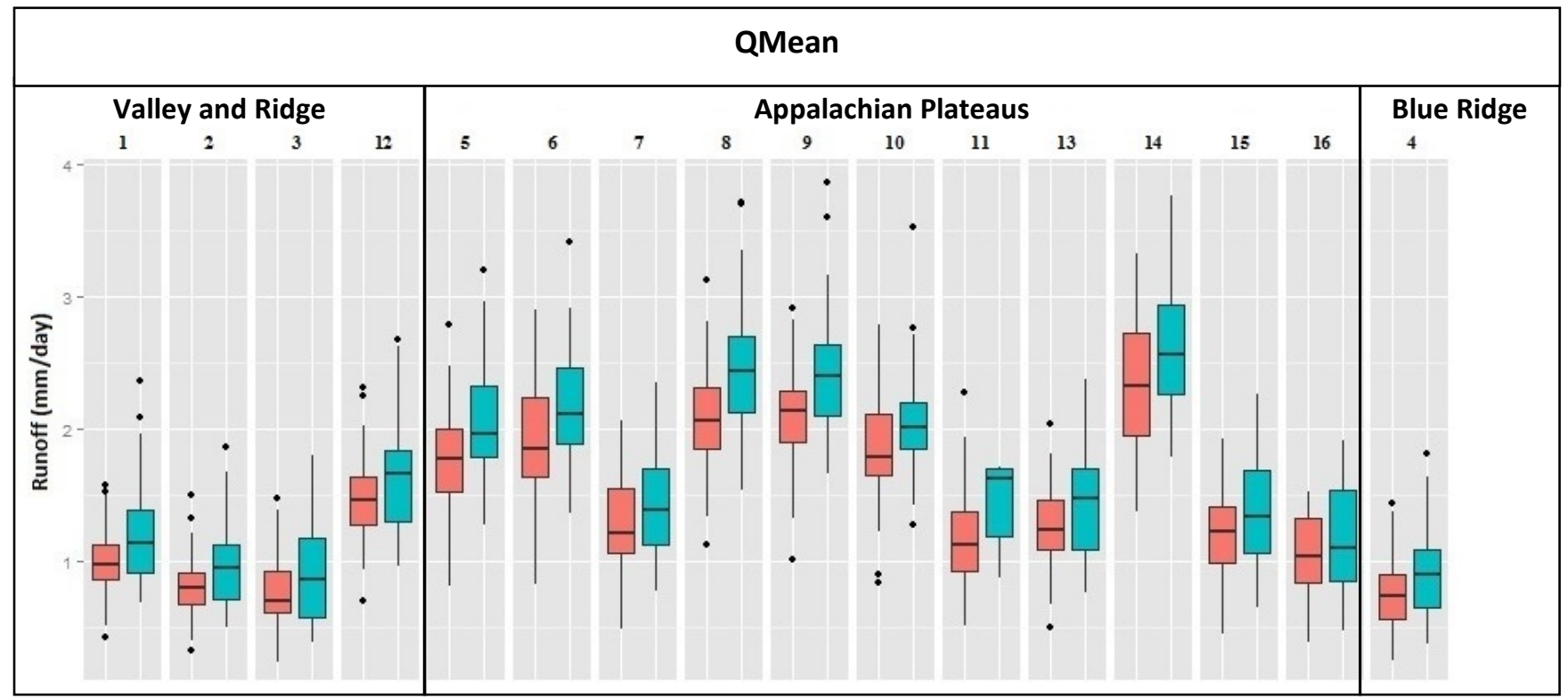

Figure 4. Pre to post 1970 comparison of Qmean daily streamflow, the first boxplot in each column is the pre 1970 boxplot and the second boxplot in each column is the post boxplot. The pre to post boxplots are displaying change related to a step shift in streamflow during the early 1970's. 


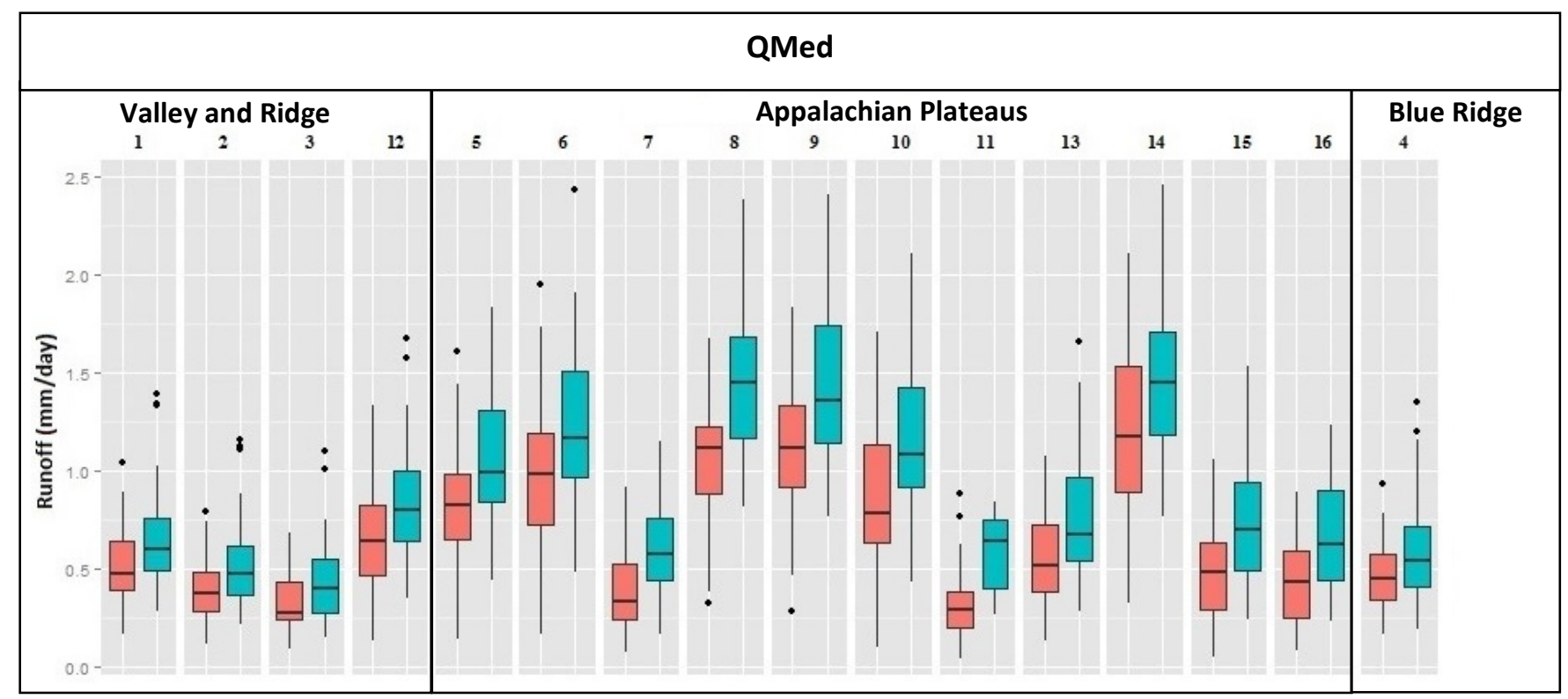

Figure 5. Pre to post 1970 comparison of Qmed daily streamflow, the first boxplot in each column is the pre 1970 boxplot and the second boxplot in each column is the post boxplot. The pre to post boxplots are displaying change related to a step shift in streamflow during the early 1970's.

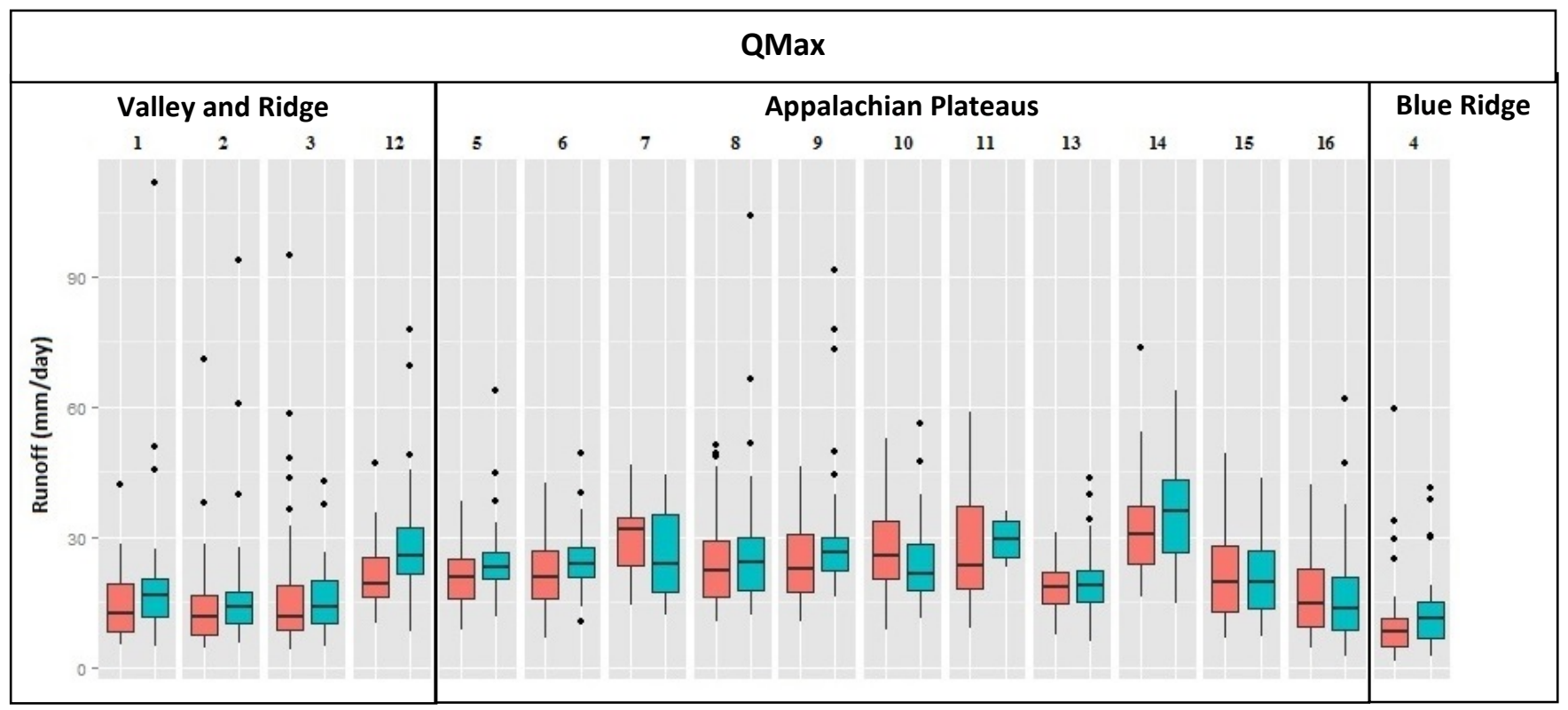

Figure 6. Pre to post 1970 comparison of Qmax daily streamflow, the first boxplot in each column is the pre 1970 boxplot and the second boxplot in each column is the post boxplot. The pre to post boxplots are displaying change related to a step shift in streamflow during the early 1970's. 


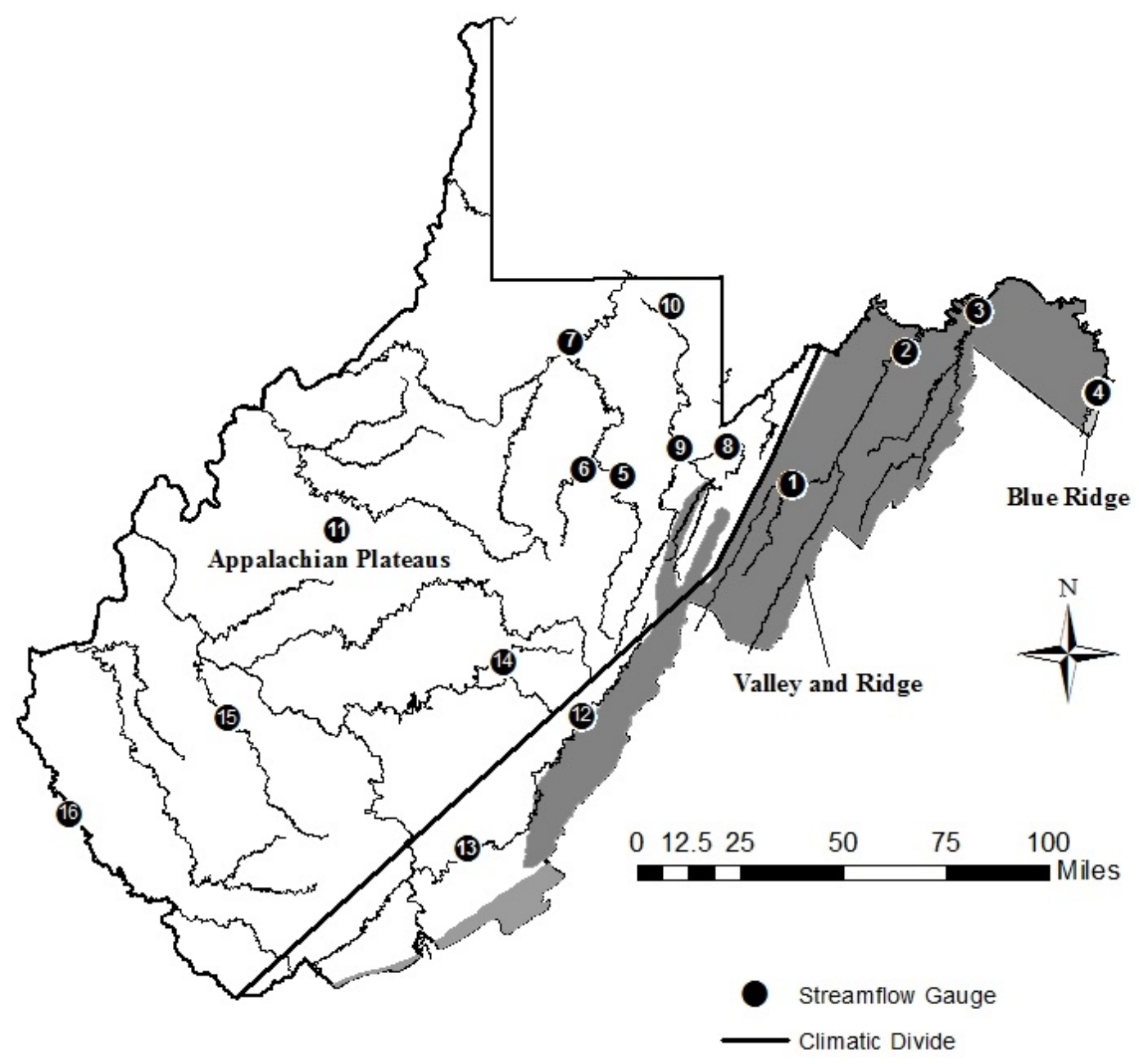

Figure 7. Locations of the 16 study watersheds with physiographic regions and the climatic divide displayed throughout West Virginia with the Climatic Divide. (Modified from Wiley 2012) 


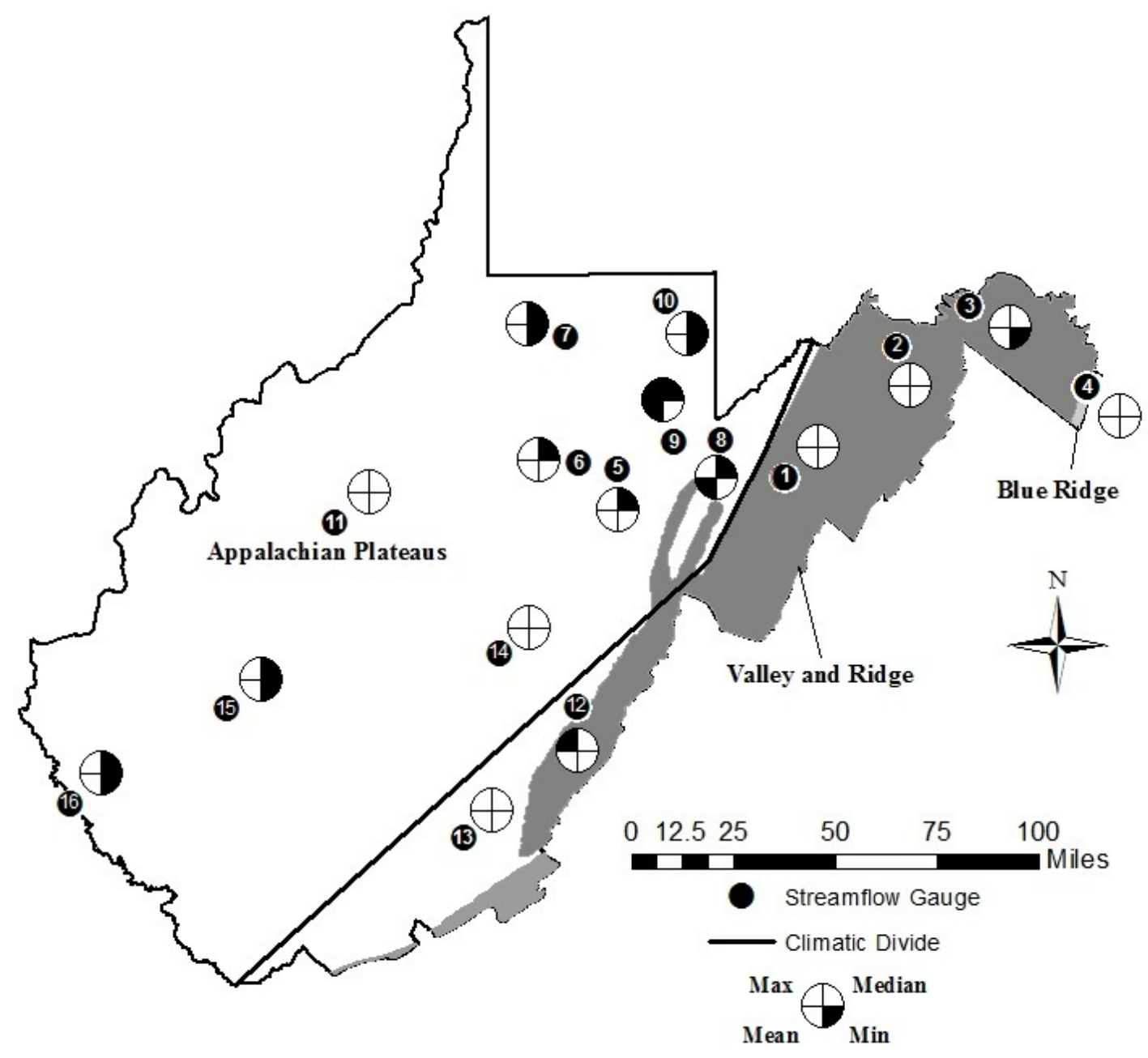

Figure 8. Watershed locations, physiographic regions, and the climatic divide throughout West Virginia. Significant trends are displayed for each watershed through the shaded circle. 
Cacapon River near Great Cacapon

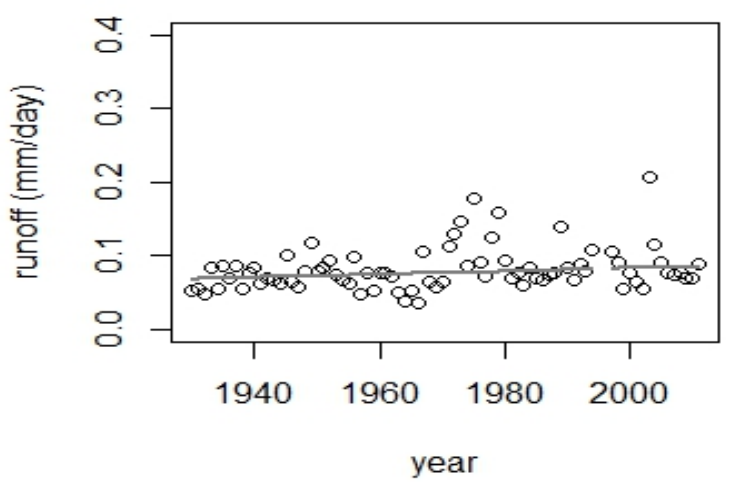

Big Coal River at Ashford

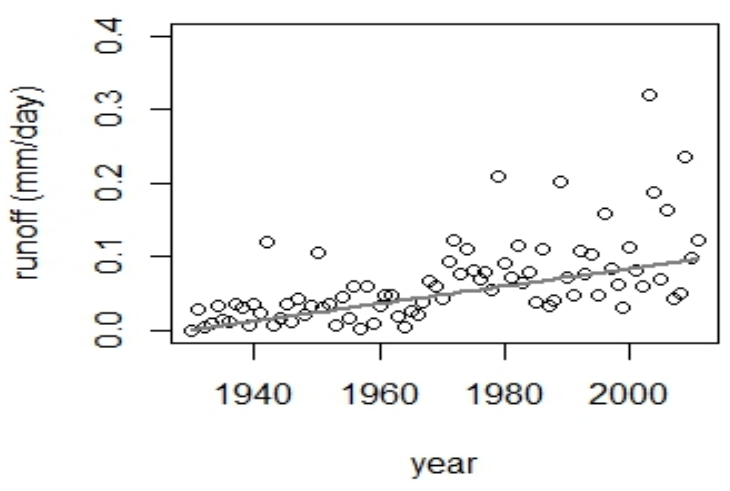

Big Sandy Creek at Rockville

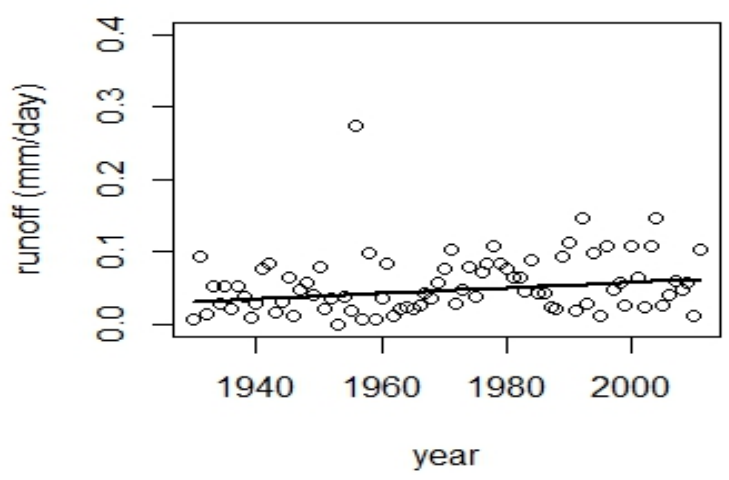

Buffalo Creek at Barrackville

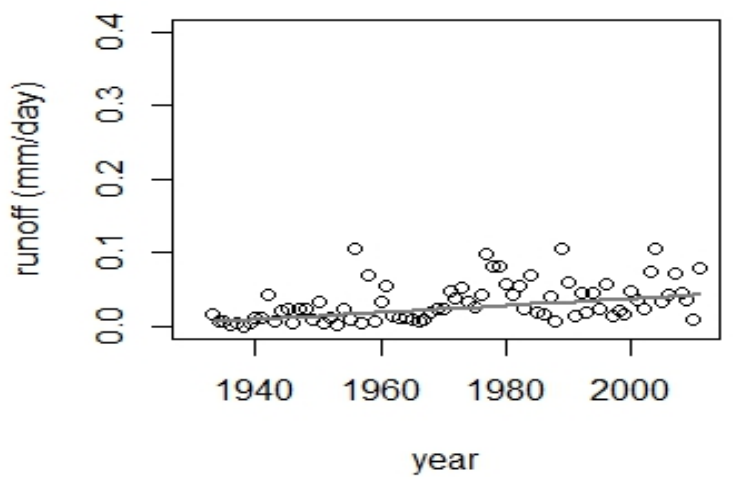

Tug Fork at Kermit

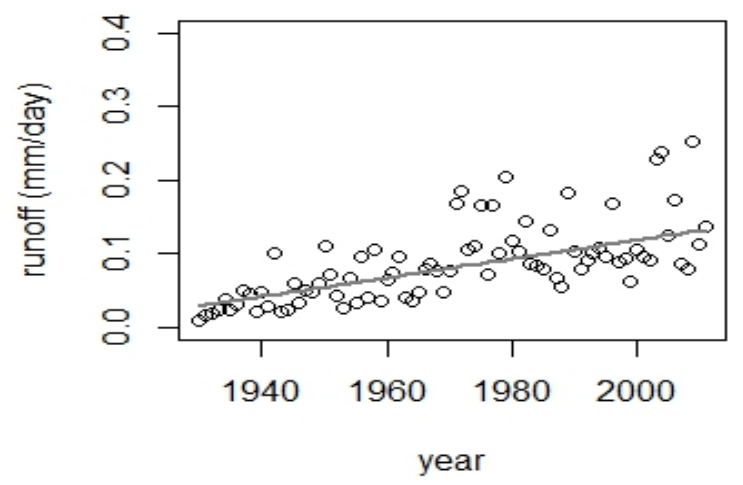

Figure 9. Time series of statistically significant trends for daily Qmin watersheds (black trend lines are MK tests and grey trend lines are MMK tests. 


\section{Blackwater River at Davis}

\section{Cheat River Near Parsons}
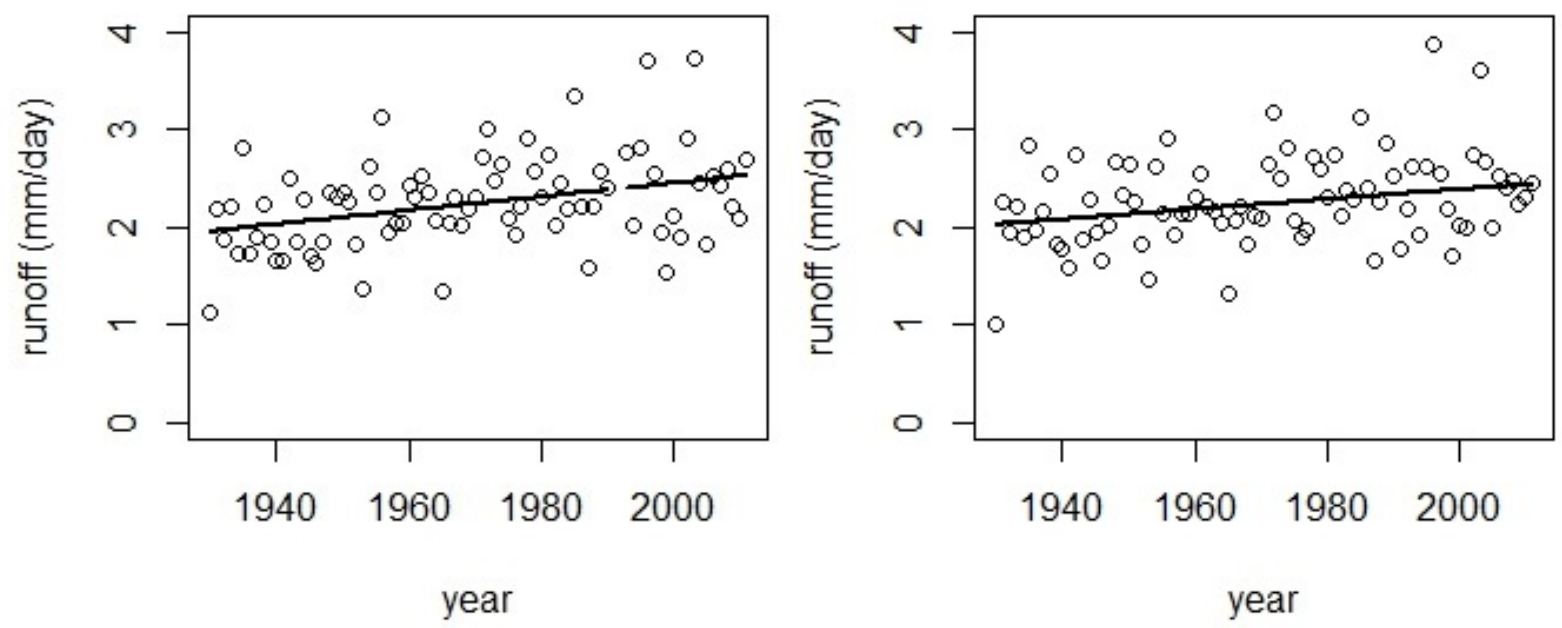

Figure 10. Time series of statistically significant trends for daily Qmean watersheds (black trend lines are MK tests and grey trend lines are MMK tests. 


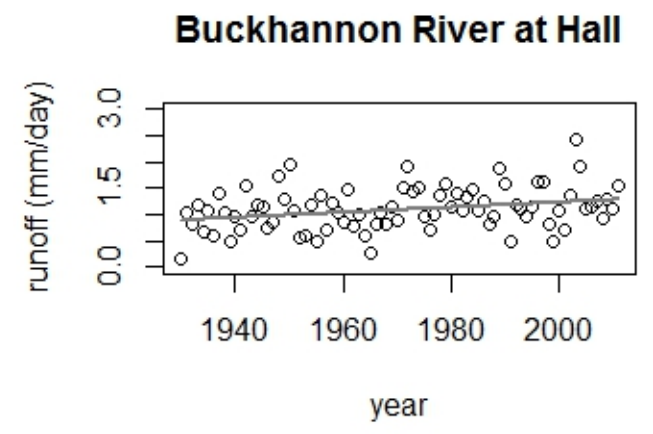

Tygart Valley River at Belington

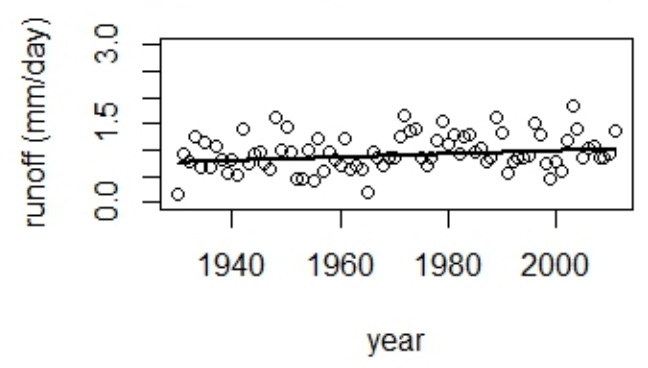

Cheat River Near Parsons

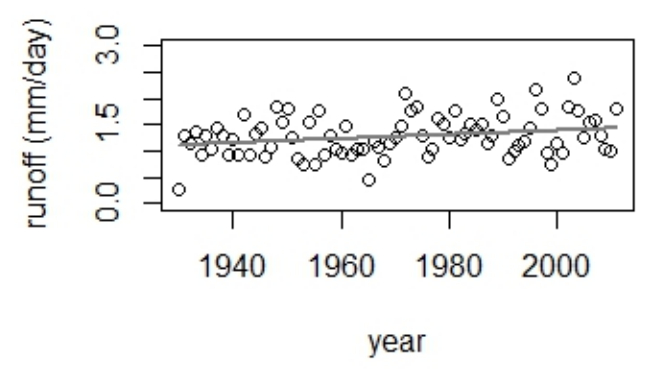

Big Sandy Creek at Rockville

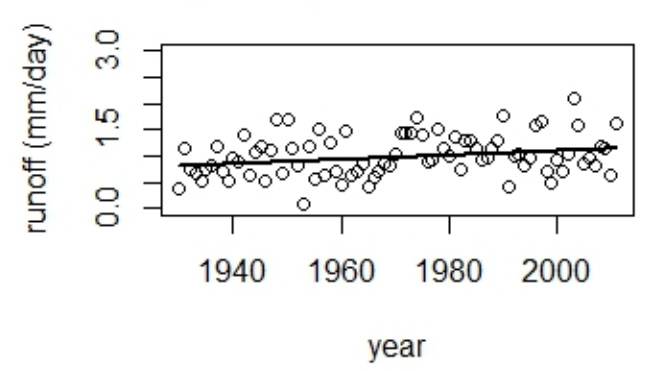

Blackwater River at Davis

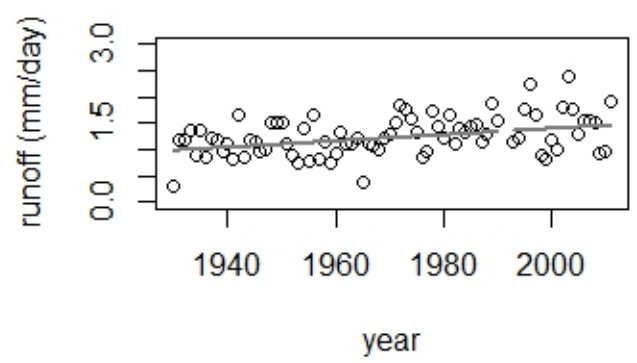

Buffalo Creek at Barrackville

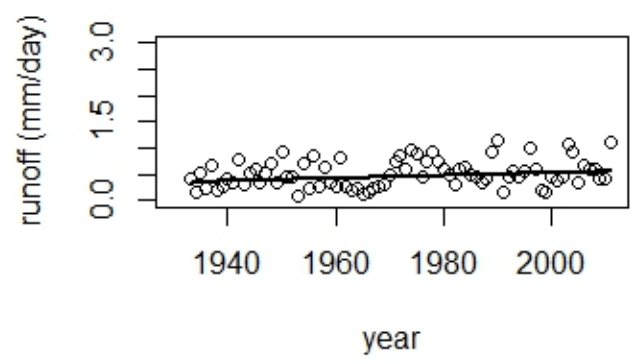

Tug Fork at Kermit

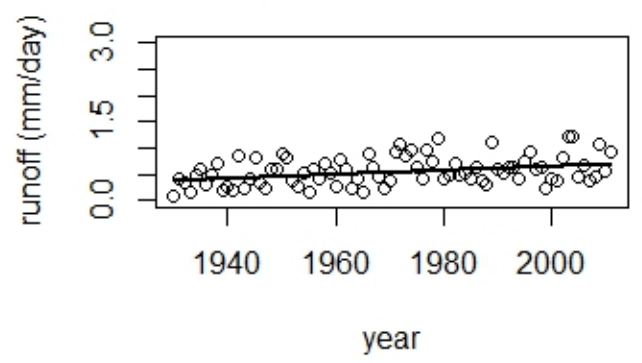

Big Coal River at Ashford

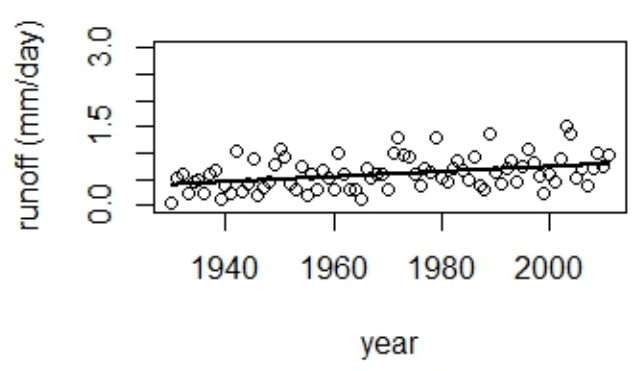

Figure 11. Time series of statistically significant trends for daily Qmed watersheds (black trend lines are MK tests and grey trend lines are MMK tests. 
Greenbrier River at Buckeye

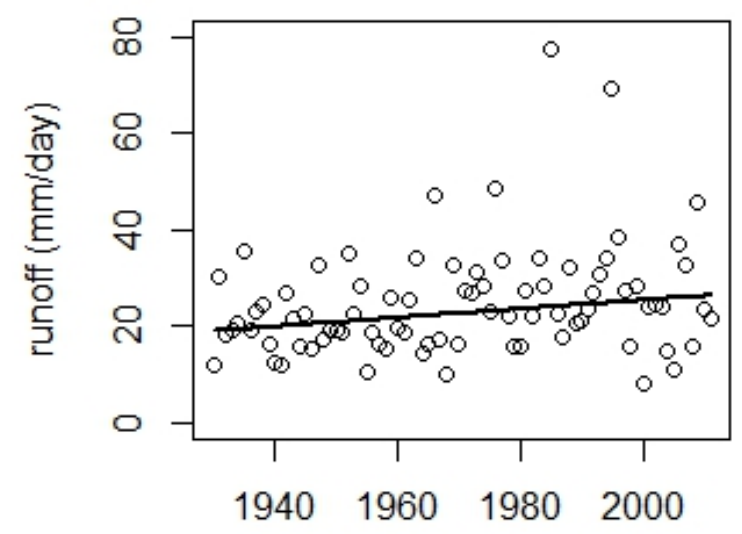

year
Cheat River Near Parsons

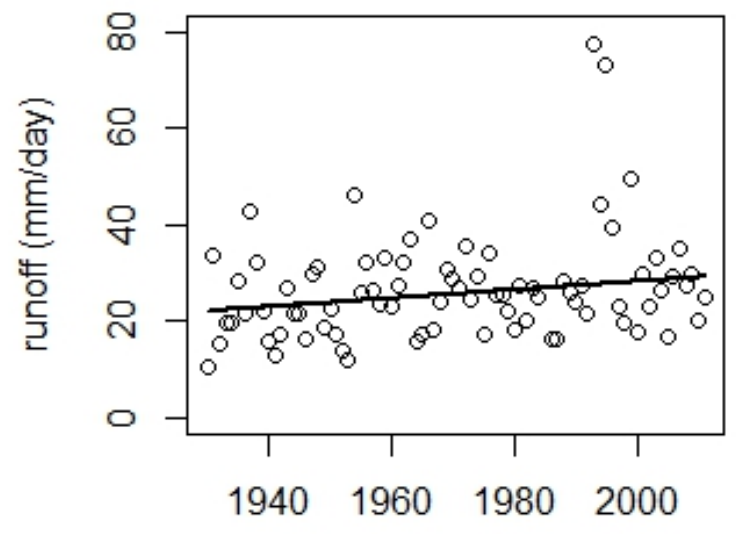

year

Figure 12. Time series of statistically significant trends for daily Qmax watersheds (black trend lines are MK tests and grey trend lines are MMK tests.

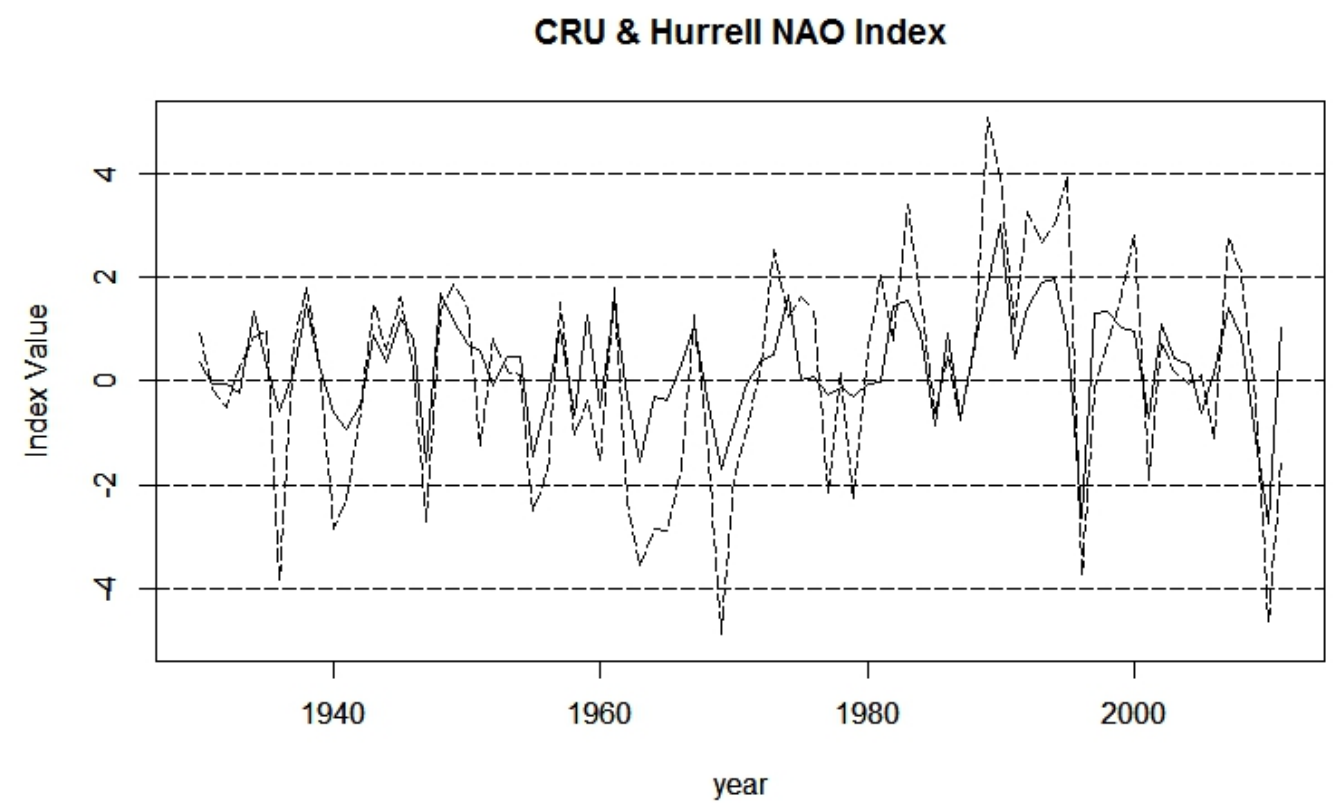

Figure 13. The solid line is the CRU NAO index and the dashed line is the Hurrell NAO index ranging from 1930-2011. This displays the difference in variance between the two indices. 
Table 1. List of the gauging stations within the study separated by physiographic regions.

\begin{tabular}{|c|c|c|c|c|c|c|}
\hline & Watershed \# & Watershed & Years & $\mathbf{K m}^{2}$ & Latitude & Longitude \\
\hline \multirow{4}{*}{$\begin{array}{c}\text { Valley and } \\
\text { Ridge }\end{array}$} & 1 & S. Branch Potomac River near Petersburg & 1930-2011 & 1686 & 38.991389 & -79.176111 \\
\hline & 2 & S. Branch Potomac River near Springfield & $"$ & 3784 & 39.446944 & -78.654444 \\
\hline & 3 & Cacapon River near Great Cacapon & $"$ & 1748 & 39.582222 & -78.310000 \\
\hline & 12 & Greenbrier River at Buckeye & & 1399 & 38.185833 & -80.130833 \\
\hline \multirow{7}{*}{$\begin{array}{c}\text { Appalachian } \\
\text { Plateaus }\end{array}$} & 5 & Tygart Valley River at Belington & " & 1052 & 39.029167 & -79.936111 \\
\hline & 6 & Buckhannon River at Hall & $"$ & 717 & 39.051111 & -80.114722 \\
\hline & 9 & Cheat River near Parsons & $"$ & 1870 & 39.122780 & -79.681389 \\
\hline & 10 & Big Sandy Creek at Rockville & $"$ & 518 & 39.621750 & -79.704472 \\
\hline & 13 & Greenbrier River at Alderson & $"$ & 3533 & 37.724167 & -80.641667 \\
\hline & 14 & Williams River at Dyer & $"$ & 332 & 38.378889 & -80.484167 \\
\hline & 15 & Big Coal River at Ashford & $"$ & 1013 & 38.179722 & -81.711667 \\
\hline
\end{tabular}


Table 2. Summary statistics for daily discharge from 1930-2011.

\begin{tabular}{|c|c|c|c|c|c|c|c|c|c|c|}
\hline & Watershed \# & Watershed & $\begin{array}{c}\text { Time } \\
\text { Period }\end{array}$ & Area $\left(\mathrm{km}^{2}\right)$ & Units & Qmin & Qmean & Qmed & Qmax & Std. Dev. \\
\hline \multirow{4}{*}{$\begin{array}{l}\text { Valley and } \\
\text { Ridge }\end{array}$} & 1 & S. Branch Potomac River near Petersburg & $1930-2011$ & 1686 & $\mathrm{~mm}_{\mathrm{day}}{ }^{-1}$ & 0.06 & 1.09 & 0.56 & 111.7 & 1.86 \\
\hline & 2 & S. Branch Potomac River near Springfield & $1930-2011$ & 3784 & $"$ & 0.00 & 0.88 & 0.43 & 93.8 & 1.68 \\
\hline & 3 & Cacapon River near Great Cacapon & $1930-2011$ & 1748 & $"$ & 0.00 & 0.81 & 0.34 & 95.0 & 1.72 \\
\hline & 12 & Greenbrier River at Buckeye & $1930-2011$ & 1399 & $"$ & 0.01 & 1.56 & 0.73 & 77.7 & 2.66 \\
\hline \multirow{11}{*}{$\begin{array}{l}\text { Appalachian } \\
\text { Plateaus }\end{array}$} & 5 & Tygart Valley River at Belington & $1930-2011$ & 1052 & $"$ & 0.00 & 1.90 & 0.94 & 63.8 & 2.94 \\
\hline & 6 & Buckhannon River at Hall & $1930-2011$ & 717 & $"$ & 0.00 & 2.04 & 1.08 & 49.5 & 2.96 \\
\hline & 7 & Buffalo Creek at Barrackville & $1930-2011$ & 300 & $"$ & 0.00 & 1.34 & 0.46 & 46.5 & 2.82 \\
\hline & 8 & Blackwater River at Davis & $1930-2011$ & 222 & $"$ & 0.00 & 2.23 & 1.22 & 104.1 & 3.21 \\
\hline & 9 & Cheat River near Parsons & $1930-2011$ & 1870 & $"$ & 0.00 & 2.27 & 1.29 & 91.6 & 3.18 \\
\hline & 10 & Big Sandy Creek at Rockville & $1930-2011$ & 518 & $"$ & 0.00 & 1.96 & 1.01 & 56.2 & 2.99 \\
\hline & 11 & W. Fork Little Kanawha River at Rocksdale & 1929-1975 & 531 & $"$ & 0.00 & 1.19 & 0.32 & 59.0 & 2.84 \\
\hline & 13 & Greenbrier River at Alderson & $1930-2011$ & 3533 & $"$ & 0.02 & 1.35 & 0.63 & 43.7 & 2.20 \\
\hline & 14 & Williams River at Dyer & $1930-2011$ & 332 & $"$ & 0.00 & 2.47 & 1.34 & 73.8 & 3.72 \\
\hline & 15 & Big Coal River at Ashford & $1930-2011$ & 1013 & $"$ & 0.00 & 1.26 & 0.58 & 49.3 & 2.22 \\
\hline & 16 & Tug Fork at Kermit & $1930-2011$ & 3315 & $"$ & 0.01 & 1.09 & 0.52 & 62.0 & 1.92 \\
\hline Blue Ridge & 4 & Shenandoah River at Millville & $1930-2011$ & 7876 & $"$ & 0.00 & 0.84 & 0.49 & 59.6 & 1.32 \\
\hline
\end{tabular}


Table 3. Mann Kendall trend analysis results including lags, test types, and streamflow change from 1930-2011 at the 16 study watersheds throughout West Virginia. The gray shaded values represent significance at an alpha of 0.05 .

\begin{tabular}{|c|c|c|c|c|c|c|c|c|c|c|c|c|c|c|c|c|c|c|}
\hline & & \multirow[b]{2}{*}{ Watershed } & \multicolumn{4}{|c|}{ Qmin } & \multicolumn{4}{|c|}{ Qmean } & \multicolumn{4}{|c|}{ Qmed } & \multicolumn{4}{|c|}{ Qmax } \\
\hline & & & lag (yr) & $\begin{array}{c}\text { Trend } \\
\text { Test }\end{array}$ & $\begin{array}{l}\text { Trend } \\
\text { Slope }\end{array}$ & $\begin{array}{l}\text { Total } \\
\text { Change }\end{array}$ & $\begin{array}{l}\text { lag } \\
\text { (yr) }\end{array}$ & $\begin{array}{l}\text { Trend } \\
\text { Test }\end{array}$ & $\begin{array}{l}\text { Trend } \\
\text { Slope }\end{array}$ & $\begin{array}{l}\text { Total } \\
\text { Change }\end{array}$ & $\begin{array}{l}\text { lag } \\
\text { (yr) }\end{array}$ & $\begin{array}{c}\text { Trend } \\
\text { Test }\end{array}$ & $\begin{array}{l}\text { Trend } \\
\text { Slope }\end{array}$ & $\begin{array}{l}\text { Total } \\
\text { Change }\end{array}$ & $\begin{array}{l}\text { lag } \\
\text { (yr) }\end{array}$ & $\begin{array}{l}\text { Trend } \\
\text { Test }\end{array}$ & $\begin{array}{l}\text { Trend } \\
\text { Slope }\end{array}$ & Total Change \\
\hline \multirow{4}{*}{ 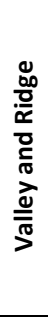 } & 1 & $\begin{array}{l}\text { S. Branch Potomac River } \\
\text { near Petersburg }\end{array}$ & - & MK & 0.00000 & 0.000 & 5 & МMК & 0.0029 & 0.24 & 1 & ММК & 0.0017 & 0.14 & - & MK & 0.0570 & 4.67 \\
\hline & 2 & $\begin{array}{l}\text { S. Branch Potomac River } \\
\text { near Springfield }\end{array}$ & - & MK & 0.00002 & 0.001 & 5 & МMК & 0.0024 & 0.20 & - & MK & 0.0015 & 0.12 & - & MK & 0.0119 & 0.98 \\
\hline & 3 & $\begin{array}{c}\text { Cacapon River near Great } \\
\text { Cacapon }\end{array}$ & 3 & MMK & 0.00021 & 0.017 & - & MK & 0.0013 & 0.11 & - & MK & 0.0009 & 0.07 & - & MK & 0.0137 & -1.12 \\
\hline & 12 & $\begin{array}{c}\text { Greenbrier River at } \\
\text { Buckeye }\end{array}$ & - & MK & 0.00018 & 0.015 & - & MK & 0.0028 & 0.23 & - & MK & 0.0020 & 0.16 & - & MK & 0.0912 & 7.48 \\
\hline \multirow{11}{*}{ 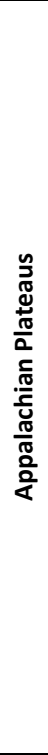 } & 5 & $\begin{array}{c}\text { Tygart Valley River at } \\
\text { Belington }\end{array}$ & - & MK & 0.00000 & 0.000 & - & MK & 0.0033 & 0.27 & - & MK & 0.0032 & 0.26 & - & MK & 0.0500 & 4.10 \\
\hline & 6 & Buckhannon River at Hall & - & MK & 0.00017 & 0.014 & - & MK & 0.0033 & 0.27 & 1 & МMK & 0.0049 & 0.40 & - & MK & 0.0306 & 2.51 \\
\hline & 7 & $\begin{array}{l}\text { Buffalo Creek at } \\
\text { Barrackville }\end{array}$ & 5 & МMK & 0.00047 & 0.038 & - & MK & 0.0008 & 0.06 & - & MK & 0.0026 & 0.21 & - & MK & 0.0529 & -4.34 \\
\hline & 8 & Blackwater River at Davis & - & MK & 0.00044 & 0.036 & - & MK & 0.0070 & 0.57 & 2 & MMK & 0.0059 & 0.48 & - & MK & 0.0563 & 4.62 \\
\hline & 9 & Cheat River near Parsons & - & MK & 0.00028 & 0.023 & - & MK & 0.0051 & 0.42 & 1 & MMK & 0.0040 & 0.33 & - & MK & 0.0872 & 7.15 \\
\hline & 10 & $\begin{array}{c}\text { Big Sandy Creek at } \\
\text { Rockville }\end{array}$ & - & MK & 0.00039 & 0.032 & - & MK & 0.0018 & 0.15 & - & MK & 0.0041 & 0.34 & - & MK & 0.0660 & -5.41 \\
\hline & 11 & $\begin{array}{l}\text { W. Fork Little Kanawha } \\
\text { River at Rocksdale }\end{array}$ & - & MK & 0.00005 & 0.004 & - & MK & 0.0028 & 0.23 & - & MK & 0.0000 & 0.00 & - & MK & 0.0293 & 2.40 \\
\hline & 13 & $\begin{array}{c}\text { Greenbrier River at } \\
\text { Alderson }\end{array}$ & - & MK & 0.00000 & 0.000 & - & MK & 0.0025 & 0.21 & - & MK & 0.0022 & 0.18 & - & MK & $0 . \overline{-}$ & -0.93 \\
\hline & 14 & Williams River at Dyer & - & MK & 0.00007 & 0.006 & - & MK & 0.0040 & 0.33 & - & MK & 0.0032 & 0.26 & 1 & ММк & 0.0543 & 4.45 \\
\hline & 15 & Big Coal River at Ashford & 5 & MMK & 0.00120 & 0.098 & - & MK & 0.0024 & 0.20 & - & MK & 0.0048 & 0.39 & - & MK & $0 . \overline{0277}$ & -2.27 \\
\hline & 16 & Tug Fork at Kermit & 5 & МMK & 0.00130 & 0.107 & - & MK & 0.0013 & 0.11 & - & MK & 0.0039 & 0.32 & - & MK & $\begin{array}{c}- \\
0.0310\end{array}$ & -2.54 \\
\hline $\begin{array}{l}\stackrel{0}{0} \\
\frac{0}{\sigma 0} \\
\frac{0}{0} \\
\frac{\partial}{0}\end{array}$ & 4 & $\begin{array}{c}\text { Shenandoah River at } \\
\text { Millville }\end{array}$ & - & MK & 0.00034 & 0.028 & - & MK & 0.0018 & 0.15 & - & MK & 0.0014 & 0.11 & - & MK & 0.0311 & 2.55 \\
\hline
\end{tabular}


Table 4. Pearson correlation between mean winter (DJFM) CRU NAO and mean winter (DJF) CRU modeled precipitation. The gray shaded values represent significance at an alpha of 0.05 .

\begin{tabular}{|c|c|c|c|}
\hline Watershed \# & Watershed & Pearson's R & \\
\hline 1 & S. Branch Potomac River near Petersburg & 0.23 & \multirow{4}{*}{ Valley and Ridge } \\
\hline 2 & S. Branch Potomac River near Springfield & 0.20 & \\
\hline 3 & Cacapon River near Great Cacapon & 0.26 & \\
\hline 12 & Greenbrier River at Buckeye & 0.32 & \\
\hline 5 & Tygart Valley River at Belington & 0.18 & \multirow{11}{*}{ Appalachian Plateaus } \\
\hline 6 & Buckhannon River at Hall & 0.12 & \\
\hline 7 & Buffalo Creek at Barrackville & 0.20 & \\
\hline 8 & Blackwater River at Davis & 0.09 & \\
\hline 9 & Cheat River near Parsons & 0.17 & \\
\hline 10 & Big Sandy Creek at Rockville & 0.17 & \\
\hline 13 & Greenbrier River at Alderson & 0.23 & \\
\hline 14 & Williams River at Dyer & 0.25 & \\
\hline 15 & Big Coal River at Ashford & 0.17 & \\
\hline 16 & Tug Fork at Kermit & 0.19 & \\
\hline 11 & West Fork Little Kanawha River at Rocksdale & 0.20 & \\
\hline 4 & Shenandoah River at Millville & 0.19 & Blue Ridge \\
\hline
\end{tabular}


Table 5. Spearman's Rho seasonal correlation with CRU mean winter (DJF) NAO and mean seasonal streamflow. The gray shaded values represent significance at an alpha of 0.05 .

\begin{tabular}{|c|c|c|c|c|c|c|c|c|c|}
\hline & \multicolumn{2}{|c|}{ Winter } & \multicolumn{2}{|c|}{ Spring } & \multicolumn{2}{|c|}{ Summer } & \multicolumn{2}{|c|}{ Fall } & \\
\hline & p-value & rho & p-value & rho & p-value & rho & p-value & rho & \\
\hline 1 & 0.37 & 0.09 & 0.89 & 0.01 & 0.92 & 0.01 & 0.79 & 0.02 & \\
\hline 2 & 0.37 & 0.09 & 0.83 & -0.02 & 0.85 & 0.01 & 0.98 & 0.00 & Valley and \\
\hline 3 & 0.68 & 0.04 & 0.95 & -0.00 & 0.70 & -0.04 & 0.91 & -0.01 & Ridge \\
\hline 12 & 0.31 & 0.11 & 0.96 & -0.00 & 0.46 & 0.08 & 0.43 & 0.08 & \\
\hline 5 & 0.22 & 0.13 & 0.57 & 0.06 & 0.88 & -0.01 & 0.51 & 0.07 & \\
\hline 6 & 0.26 & 0.12 & 0.45 & 0.08 & 0.87 & 0.01 & 0.64 & 0.05 & \\
\hline 7 & 0.29 & 0.11 & 0.58 & 0.06 & 0.62 & -0.05 & 0.64 & 0.05 & \\
\hline 8 & 0.22 & 0.13 & 0.21 & -0.13 & 0.67 & -0.04 & 0.71 & -0.04 & \\
\hline 9 & 0.08 & 0.19 & 0.73 & -0.03 & 0.74 & -0.03 & 0.74 & 0.03 & \\
\hline 10 & 0.19 & 0.14 & 0.72 & -0.03 & 0.47 & -0.08 & 0.91 & 0.01 & $\begin{array}{c}\text { Appalacnian } \\
\text { Plateaus }\end{array}$ \\
\hline 13 & 0.41 & 0.09 & 0.71 & 0.04 & 0.67 & 0.04 & 0.67 & 0.04 & \\
\hline 14 & 0.27 & 0.12 & 0.60 & -0.05 & 0.98 & 0.00 & 0.62 & 0.05 & \\
\hline 15 & 0.94 & 0.00 & 0.42 & 0.08 & 0.64 & -0.05 & 0.24 & 0.13 & \\
\hline 16 & 0.78 & -0.03 & 0.58 & 0.06 & 0.73 & -0.03 & 0.73 & -0.03 & \\
\hline 11 & 0.01 & 0.37 & 0.52 & 0.10 & 0.66 & 0.07 & 0.02 & 0.35 & \\
\hline 4 & 0.99 & -0.00 & 0.47 & 0.08 & 0.76 & 0.03 & 0.96 & 0.00 & Blue Ridge \\
\hline
\end{tabular}


Table 6. Spearman's Rho seasonal correlation with CRU mean winter (DJFM) NAO and mean seasonal streamflow. The gray shaded values represent significance at an alpha of 0.05 .

\begin{tabular}{|c|c|c|c|c|c|c|c|c|c|}
\hline & \multicolumn{2}{|c|}{ Winter } & \multicolumn{2}{|c|}{ Spring } & \multicolumn{2}{|c|}{ Summer } & \multicolumn{2}{|c|}{ Fall } & \\
\hline & p-value & rho & $p$-value & rho & p-value & rho & p-value & rho & \\
\hline 1 & 0.58 & 0.06 & 0.88 & 0.01 & 0.78 & 0.03 & 0.60 & 0.05 & \\
\hline 2 & 0.58 & 0.06 & 0.85 & -0.01 & 0.89 & 0.01 & 0.81 & 0.02 & Valley and \\
\hline 3 & 0.73 & 0.03 & 0.81 & -0.02 & 0.69 & -0.04 & 0.87 & 0.01 & Ridge \\
\hline 12 & 0.59 & 0.05 & 0.70 & 0.04 & 0.23 & 0.13 & 0.23 & 0.13 & \\
\hline 5 & 0.49 & 0.07 & 0.20 & 0.14 & 0.59 & 0.05 & 0.29 & 0.11 & \\
\hline 6 & 0.51 & 0.07 & 0.15 & 0.15 & 0.29 & 0.11 & 0.46 & 0.08 & \\
\hline 7 & 0.40 & 0.09 & 0.29 & 0.11 & 0.76 & -0.03 & 0.60 & 0.05 & \\
\hline 8 & 0.48 & 0.07 & 0.60 & -0.05 & 0.96 & 0.00 & 0.99 & 0.00 & \\
\hline 9 & 0.23 & 0.13 & 0.71 & 0.04 & 0.88 & 0.01 & 0.52 & 0.07 & \\
\hline 10 & 0.30 & 0.11 & 0.80 & 0.02 & 0.80 & -0.02 & 0.63 & 0.05 & $\begin{array}{l}\text { Appalacman } \\
\text { Plateaus }\end{array}$ \\
\hline 13 & 0.67 & 0.04 & 0.51 & 0.07 & 0.36 & 0.10 & 0.39 & 0.09 & \\
\hline 14 & 0.61 & 0.05 & 0.92 & -0.01 & 0.63 & 0.05 & 0.42 & 0.08 & \\
\hline 15 & 0.84 & -0.02 & 0.41 & 0.09 & 0.88 & 0.01 & 0.13 & 0.16 & \\
\hline 16 & 0.79 & -0.02 & 0.41 & 0.09 & 0.54 & 0.06 & 0.54 & 0.06 & \\
\hline 11 & 0.06 & 0.29 & 0.21 & 0.19 & 0.49 & 0.11 & 0.07 & 0.27 & \\
\hline 4 & 0.95 & 0.00 & 0.59 & 0.58 & 0.69 & 0.04 & 0.75 & 0.03 & Blue Ridge \\
\hline
\end{tabular}


Table 7. Spearman's Rho seasonal correlation with Hurrell mean winter (DJFM) NAO and mean seasonal streamflow. The gray shaded values represent significance at an alpha of 0.05 .

\begin{tabular}{|c|c|c|c|c|c|c|c|c|c|}
\hline & \multicolumn{2}{|c|}{ Winter } & \multicolumn{2}{|c|}{ Spring } & \multicolumn{2}{|c|}{ Summer } & \multicolumn{2}{|c|}{ Fall } & \\
\hline & p-value & rho & p-value & rho & p-value & rho & p-value & rho & \\
\hline 1 & 0.35 & 0.10 & 0.88 & -0.01 & 0.41 & 0.09 & 0.69 & 0.04 & \\
\hline 2 & 0.35 & 0.10 & 0.64 & -0.05 & 0.44 & 0.08 & 0.73 & 0.03 & Valley and \\
\hline 3 & 0.59 & 0.05 & 0.66 & -0.04 & 0.80 & 0.02 & 0.78 & 0.03 & Ridge \\
\hline 12 & 0.23 & 0.13 & 0.96 & 0.00 & 0.21 & 0.13 & 0.51 & 0.07 & \\
\hline 5 & 0.21 & 0.13 & 0.30 & 0.11 & 0.44 & 0.08 & 0.63 & 0.05 & \\
\hline 6 & 0.26 & 0.12 & 0.19 & 0.14 & 0.23 & 0.13 & 0.67 & 0.04 & \\
\hline 7 & 0.06 & 0.20 & 0.41 & 0.09 & 0.70 & 0.04 & 0.46 & 0.08 & \\
\hline 8 & 0.23 & 0.13 & 0.53 & -0.07 & 0.55 & 0.06 & 0.79 & -0.02 & \\
\hline 9 & 0.08 & 0.19 & 0.84 & 0.02 & 0.65 & 0.05 & 0.95 & 0.00 & \\
\hline 10 & 0.08 & 0.19 & 0.81 & 0.02 & 0.65 & 0.05 & 0.95 & 0.00 & Appalachian \\
\hline 13 & 0.29 & 0.11 & 0.74 & 0.03 & 0.22 & 0.13 & 0.47 & 0.08 & \\
\hline 14 & 0.21 & 0.13 & 0.85 & 0.02 & 0.66 & 0.04 & 0.45 & 0.08 & \\
\hline 15 & 0.48 & 0.07 & 0.36 & 0.10 & 0.88 & 0.01 & 0.43 & 0.08 & \\
\hline 16 & 0.49 & 0.07 & 0.50 & 0.07 & 0.58 & 0.06 & 0.58 & 0.06 & \\
\hline 11 & 0.00 & 0.41 & 0.13 & 0.23 & 0.21 & 0.19 & 0.03 & 0.33 & \\
\hline 4 & 0.88 & 0.01 & 0.68 & 0.04 & 0.39 & 0.09 & 0.57 & 0.06 & Blue Ridge \\
\hline
\end{tabular}


Table 8. Watershed characterization for watersheds within the Appalachian Plateaus.

\begin{tabular}{|c|c|c|c|c|c|c|c|c|}
\hline Watershed & & $\begin{array}{c}\text { Stream } \\
\text { Slope } \\
\text { (degrees) }\end{array}$ & $\begin{array}{c}\text { Watershed } \\
\text { Slope (degrees) }\end{array}$ & $\begin{array}{c}\text { Channel Elev. } \\
\text { (m) }\end{array}$ & $\begin{array}{l}\text { Drainage } \\
\text { Elev. (m) }\end{array}$ & $\begin{array}{l}\text { Drainage } \\
\text { Direction }\end{array}$ & \multicolumn{2}{|c|}{ Dominant Landcover (\%) } \\
\hline \multirow{3}{*}{5} & $\min$ & 0 & 0 & 515 & 515 & \multirow{3}{*}{$\mathrm{N}$} & Deciduous Forest & 81 \\
\hline & mean & 0.5 & 14.2 & 673 & 777 & & Pasture/Hay & 6 \\
\hline & $\max$ & 13.66 & 68.8 & 1176 & 1447 & & Developed Open Space & 5 \\
\hline \multirow{3}{*}{6} & $\min$ & 0 & 0 & 418 & 418 & \multirow{3}{*}{$\mathrm{N}$} & Deciduous Forest & 78 \\
\hline & mean & 0.4 & 12.1 & 556 & 629 & & Pasture/Hay & 8 \\
\hline & $\max$ & 10.4 & 57.4 & 982 & 1197 & & Developed, Open Space & 6 \\
\hline \multirow{3}{*}{7} & $\min$ & 0 & 0 & 270 & 270 & \multirow{3}{*}{ E } & Deciduous Forest & 84 \\
\hline & mean & 0.2 & 15.7 & 309 & 375 & & Developed, Open Space & 7 \\
\hline & $\max$ & 8.3 & 55.8 & 348 & 519 & & Pasture/Hay & 4 \\
\hline \multirow{3}{*}{8} & $\min$ & 0 & 0 & 935 & 935 & \multirow{3}{*}{ W } & Deciduous Forest & 60 \\
\hline & mean & 0.2 & 5.6 & 972 & 1023 & & Evergreen Forest & 10 \\
\hline & $\max$ & 4.4 & 56.1 & 1092 & 1342 & & Woody Wetlands & 8 \\
\hline \multirow{3}{*}{9} & $\min$ & 0 & 0 & 488 & 486 & \multirow{3}{*}{$\mathrm{N}$} & Deciduous Forest & 66 \\
\hline & mean & 0.7 & 12.4 & 871 & 995 & & Evergreen Forest & 13 \\
\hline & $\max$ & 32.3 & 68.6 & 1324 & 1477 & & Mixed Forest & 11 \\
\hline \multirow{3}{*}{10} & $\min$ & 0 & 0 & 405 & 403 & \multirow{3}{*}{$S$} & Deciduous Forest & 74 \\
\hline & mean & 0.4 & 7.6 & 542 & 602 & & Pasture/Hay & 12 \\
\hline & $\max$ & 14.7 & 57.5 & 809 & 944 & & Developed, Open Space & 5 \\
\hline \multirow{3}{*}{13} & $\min$ & 0 & 0 & 467 & 467 & \multirow{3}{*}{$S$} & Deciduous Forest & 79 \\
\hline & mean & 0.6 & 14.5 & 730 & 835 & & Pasture/Hay & 6 \\
\hline & $\max$ & 24.8 & 75.2 & 1244 & 1478 & & Evergreen Forest & 6 \\
\hline \multirow{3}{*}{14} & $\min$ & 0 & 0 & 670 & 670 & \multirow{3}{*}{ W } & Deciduous Forest & 71 \\
\hline & mean & 1.1 & 13.5 & 919 & 1070 & & Mixed Forest & 19 \\
\hline & $\max$ & 11 & 55.9 & 1287 & 1434 & & Evergreen Forest & 7 \\
\hline \multirow{3}{*}{15} & $\min$ & 0 & 0 & 189 & 189 & \multirow{3}{*}{ NW } & Deciduous Forest & 80 \\
\hline & mean & 0.6 & 21.5 & 389 & 528 & & Grassland/Herbaceous & 7 \\
\hline & $\max$ & 15.46 & 72.5 & 692 & 1072 & & Pasture/Hay & 4 \\
\hline \multirow{3}{*}{16} & $\min$ & 0 & 0 & 176 & 176 & \multirow{3}{*}{ NW } & Deciduous Forest & 81 \\
\hline & mean & 0.5 & 23.3 & 356 & 489 & & Grassland/Herbaceous & 8 \\
\hline & $\max$ & 28.1 & 74.3 & 764 & 1039 & & Developed, Open Space & 4 \\
\hline \multirow{3}{*}{11} & $\min$ & 0 & 0 & 202 & 202 & \multirow{3}{*}{ NW } & Deciduous Forest & 90 \\
\hline & mean & 0.2 & 19 & 241 & 315 & & Pasture/Hay & 5 \\
\hline & $\max$ & 4.2 & 59 & 319 & 484 & & Developed, Open Space & 4 \\
\hline
\end{tabular}


Table 9. Watershed characterization for the watersheds within the Valley and Blue Ridge physiographic regions.

\begin{tabular}{|c|c|c|c|c|c|c|c|c|c|}
\hline Watershed & & $\begin{array}{l}\text { Stream Slope } \\
\text { (degrees) }\end{array}$ & $\begin{array}{c}\text { Watershed } \\
\text { Slope } \\
\text { (degrees) }\end{array}$ & $\begin{array}{l}\text { Stream Channel } \\
\text { Elevation }(\mathrm{m})\end{array}$ & $\begin{array}{l}\text { Watershed } \\
\text { Elevation }(\mathrm{m})\end{array}$ & $\begin{array}{l}\text { Drainage } \\
\text { Direction }\end{array}$ & Dominant Landco & $r(\%)$ & \\
\hline \multirow{3}{*}{1} & $\min$ & 0.0 & 0 & 297 & 295 & \multirow{3}{*}{$\mathrm{N}$} & Deciduous Forest & 74 & \multirow{12}{*}{ Valley and Ridge } \\
\hline & mean & 1.0 & 16 & 671 & 837 & & Pasture/Hay & 14 & \\
\hline & $\max$ & 25.9 & 74.3 & 1210 & 1482 & & Evergreen Forest & 6 & \\
\hline \multirow{3}{*}{2} & $\min$ & 0.0 & 0 & 176 & 173 & \multirow{3}{*}{$\mathrm{N}$} & Deciduous Forest & 72 & \\
\hline & mean & 0.8 & 14.9 & 509 & 654 & & Pasture/Hay & 15 & \\
\hline & $\max$ & 32.5 & 76.1 & 1210 & 1482 & & Evergreen Forest & 5 & \\
\hline \multirow{3}{*}{3} & $\min$ & 0 & 0 & 139 & 139 & \multirow{3}{*}{$\mathrm{N}$} & Deciduous Forest & 77 & \\
\hline & mean & 0.5 & 11.2 & 374 & 482 & & Pasture/Hay & 11 & \\
\hline & $\max$ & 15 & 71.9 & 859 & 1017 & & Mixed Forest & 5 & \\
\hline \multirow{3}{*}{12} & $\min$ & 0 & 0 & 641 & 637 & \multirow{3}{*}{$S$} & Deciduous Forest & 78 & \\
\hline & mean & 0.6 & 15 & 831 & 945 & & Evergreen Forest & 6 & \\
\hline & $\max$ & 10.7 & 65.7 & 1244 & 1478 & & Mixed Forest & 6 & \\
\hline \multirow{3}{*}{4} & $\min$ & 0 & 0 & 90 & 89 & \multirow{3}{*}{$\mathrm{N}$} & Deciduous Forest & 47 & \multirow{3}{*}{ Blue Ridge } \\
\hline & mean & 0.5 & 9.1 & 360 & 439 & & Pasture/Hay & 31 & \\
\hline & $\max$ & 20 & 67.8 & 1056 & 1359 & & Evergreen Forest & 6 & \\
\hline
\end{tabular}

